

\section{THE UNIVERSITY OF ILLINOIS LIBRARY \\ 499 \\ Iv $3 \xi$}

GENERAL

UBRARY 


\section{CENTRAL CIRCULATION BOOKSTACKS}

The person charging this material is responsible for its return to the library from which it was borrowed on or before the Latest Date stamped below.

Theft, mutlilation, and underlining of books aro roasons for disciplinary action and moy result in diamiseal from the University.

TO RENEW CALL TELLPHONE CENTER, 333-8400

UNIVERSITY OF ILLINOIS LIBRARY AT URBANA.CHAMPAIGN

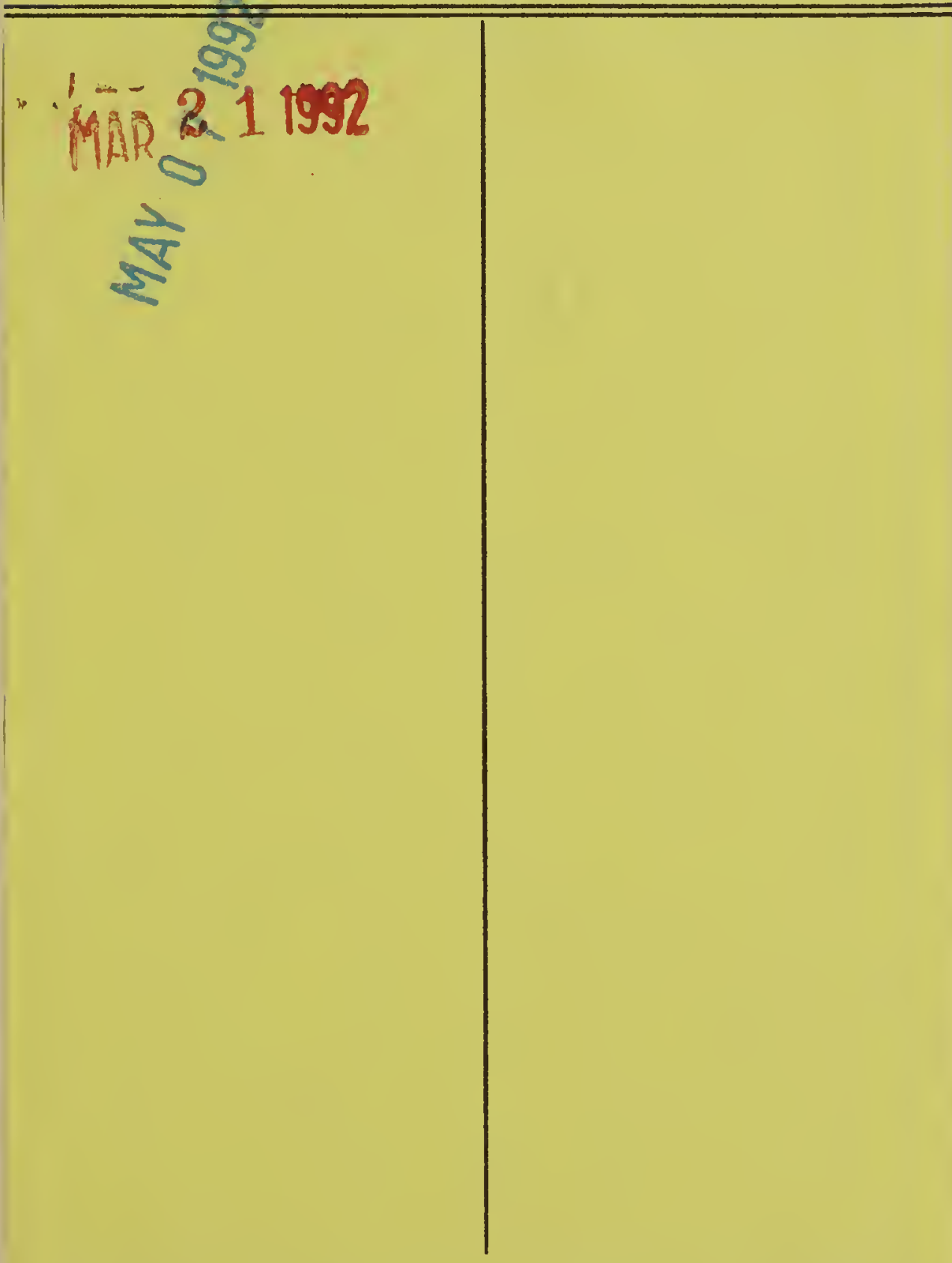

When renewing by phone, write new due date below previous due date. 



PLATE 1

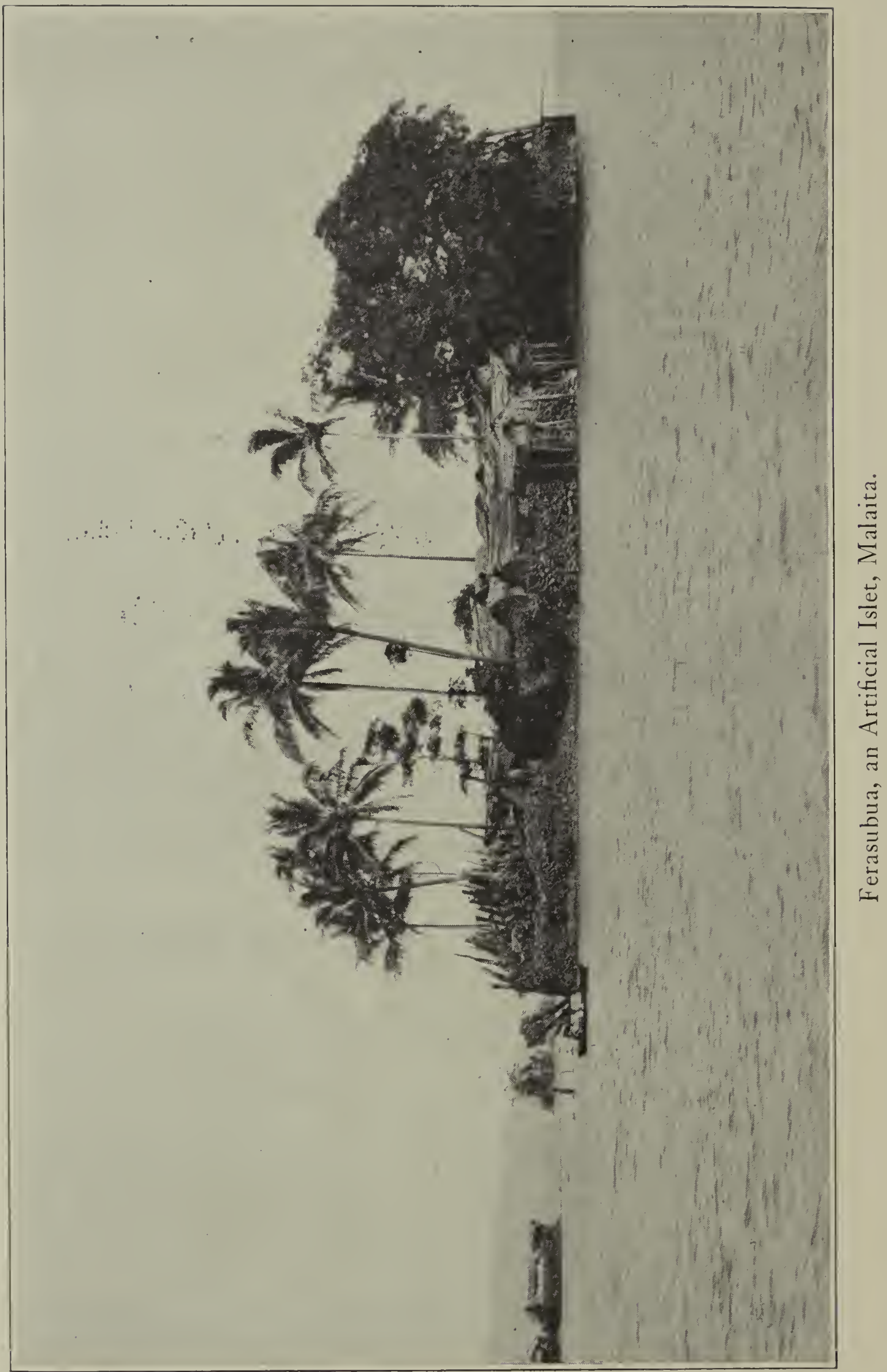




\title{
GRAMMAR AND VOCABULARY
}

\author{
or $\min$ \\ LAU LANGUAGE, \\ SOLOMON ISLANDS
}

WALTER GIIVENS, M. A IITT D. D.

MAR 141921

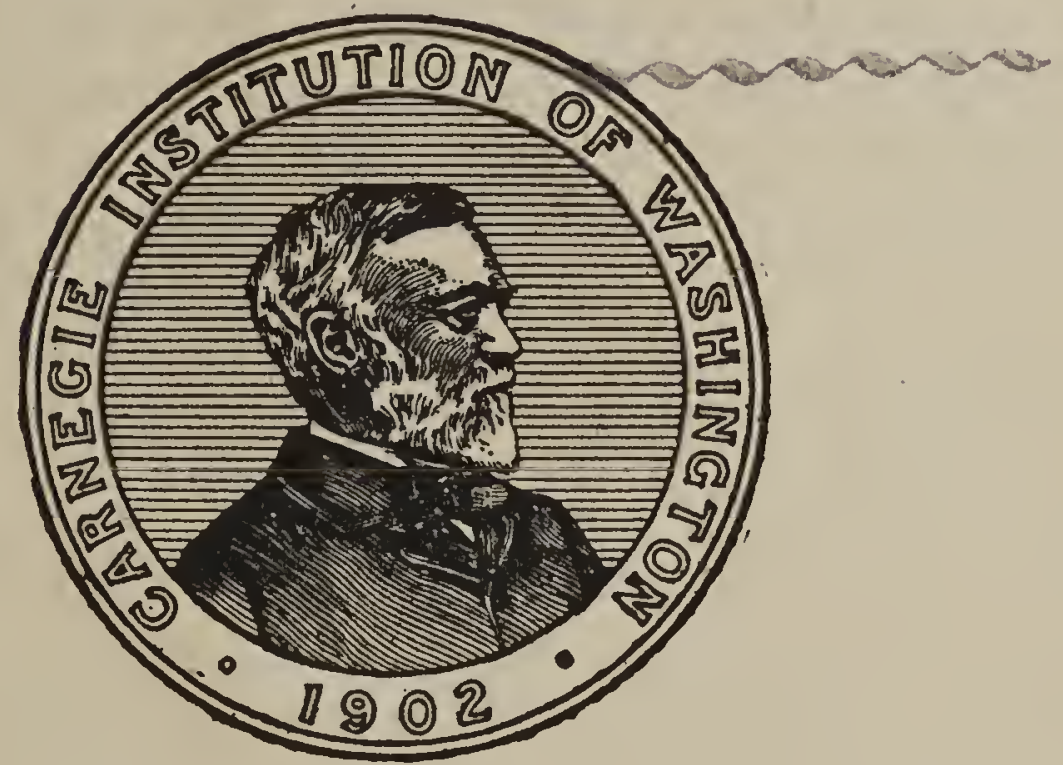

Published by the Carnegie Institution of Washington WASHINGTON, I92I 
CARNEGIE INSTITUTION OF WASHINGTON

Publication No. 300

PRESS OF GIBSON BROS., INC.

WASHINGTON 


\section{PREFACE.}

Lau is the name given to the language spoken by the inhabitants of the artificial islets which lie off the northeast coast of Big Malaita, Solomon Islands. The language spoken on the coast from Uru on the northeast to Langalanga, Alite Harbor, on the northwest of Big Malaita, is practically Lau. On the west coast there is considerable admixture of Fiu, which is the language of the bush behind the Langalanga lagoon. In Dr. Codrington's "Melanesian Languages," pp. 39 et seq., certain words are given as spoken at Alite in Langalanga. These words are probably Fiu rather than Lau.

The purest Lau is spoken at Sulufou, one of the artificial islets near Atta Cove. The inhabitants of Ai-lali, on the mainland of Big Malaita opposite the island Aio, are an offshoot of the Lau-speaking peoples. In Port Adam (Malau) on Little Malaita, some 12 miles north of Sa'a, there are two villages, Ramarama and Malede, inhabited by Lau-speaking peoples, and the inhabitants of these villages hold as a tradition that their forefathers migrated from Suraina, near Atta Cove, 80 miles away, along the coast to the north.

The Lau of this grammar and vocabulary was learned from dealings with the Port Adam natives and also from a stay of several weeks with Rev. A. I. Hopkins, at Mangoniia, on the mainland opposite the artificial islet Ferasubua.

It is not claimed that the Lau here presented is the same as the Lau of the northeast coast of Big Malaita. Doubtless owing to the Port Adam peoples being surrounded by Sa'a-speaking peoples, they have adopted $\mathrm{Sa}^{\prime} \mathrm{a}$ words and methods of speech to some extent. The women of the hill peoples above Port Adam have largely been procured as wives for the Port Adam men and thus there has been a tendency for the distinctiveness of the Lau language to disappear and for the Sa'a words to be adopted. While this tendency was perhaps not very great previous to the introduction of Christianity (for the village children 
always follow the language of the father rather than that of the mother), the teachers in the village schools, after Christianity was introduced, necessarily used the $\mathrm{Sa}^{\prime} \mathrm{a}$ books and, when translations were eventually made into Lau; words and phrases of Sa'a crept in. So far as lay in the power of the present author, he has endeavored to eliminate these Sa'a elements from the present work.

In the translations made into Lau, some use has been made of the gerundive, following the use in Sa'a; but until we have further evidence of the validity of this usage it must be regarded as not belonging to the genius of the Lau language, and it is therefore omitted here.

It will be seen that Lau is a typical Melanesian language and has few marked peculiarities. In Sa'a there is a distinctive use of the shortened forms of the pronouns of the first and second persons, $\ddot{a} u$ and ' $o$, suffixed to verbs and prepositions as object; in Lau the same shortening is not effected and the longer forms nau, oe, are used.

It has not been thought proper to represent any break in pronunciation such as occurs in Sa'a in such words, e. g., as $i a$ fish, Sa'a $i^{\prime} e$. Lau shows generally the dropping of such consonants as are dropped in $\mathrm{Sa}^{\prime} \mathrm{a}$, but it is doubtful if the same break occurs in pronunciation.

The books already printed in Lau are:

1. A translation of the English Prayer Book comprising matins and evensong, litany, baptism of adults, certain psalms and hymns, catechism, Holy Communion with Sunday collects.

2. The four Gospels.

The grammar here given is an alteration of the grammar prepared by the present writer, and printed at Norfolk Island by the Mission Press in 1914.

W. G. Ivens.

St. Paul's Vicarage,

Malvern, Victoria, 1920. 


\section{TABLE OF ABBREVIATIONS.}

adj., adjective.

adv., adverb.

art., article.

def., definite.

demons., demonstrative.

excl., exclusive (of personal pronouns, excluding the person addressed).

exclam., exclamation.

genit., genitive.

(gu), marks a noun as taking the suffixed pronouns gu, mu, na.

incl., inclusive (of personal pronouns, including the person addressed).

interj., interjection.

interr., interrogative.

metath., metathesis.

n., noun.

(na), marks a noun as taking the suffixed pronoun in the third singular only.

neg., negative.

neut., neuter.

obj., object.

part., particle.

partic., participle. pers., person, personal.

pl., plural.

poss., possessive.

pr., pronoun.

pref., prefix.

prep., preposition.

$S$, Sa'a language. See Sa'a and

Ulawa dictionary.

sing., singular.

subj., subject.

suff., suffix, suffixed.

term., termination.

tr., transitive.

$U$, Ulawa language. See Sa'a and Ulawa dictionary.

v., verb.

$v$. $i$., verb intransitive, $i$. $e$, a verb which can not take the pronoun suffixed.

$v$. $p$., verbal particle.

$v$. $t r$., verb transitive, $i$. $e_{\text {., a verb }}$ which can take the pronoun suffixed.

voc., vocative.

M. L., Codrington's Melanesian Languages. 



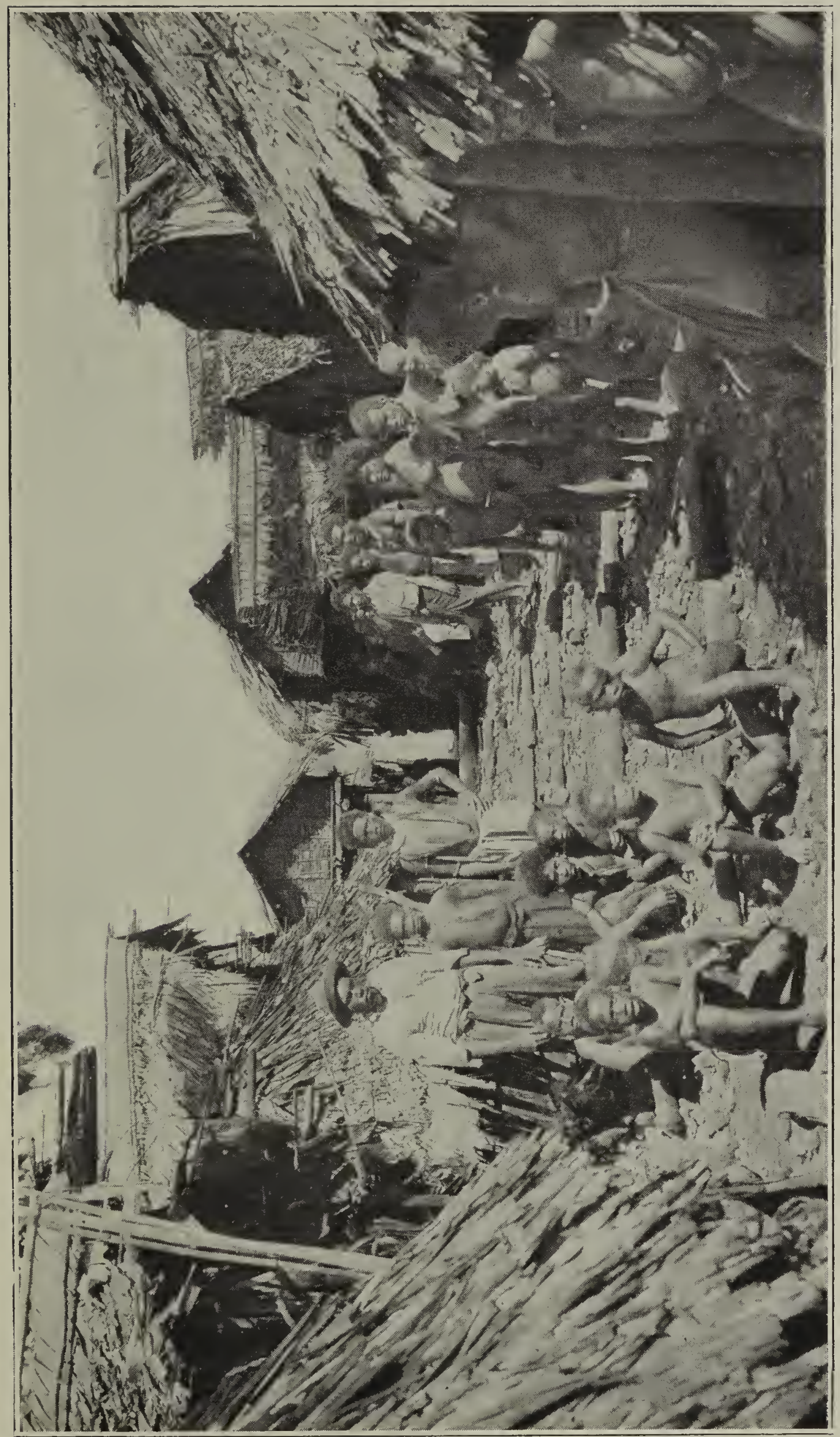

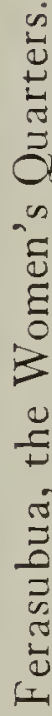





\section{LAU GRAMMAR.}

\section{THE ALPHABET.}

The vowels are $a, e, i, o, u$, with the Italian sounds. All of these vowels may be long or short, the long sound being represented by a doubling of the vowel. Closed syllables do not occur, and every word ends with a vowel. The vowel $o$ in Lau frequently represents $a$ in Sa'a: fou rock, Sa'a häu; finau hook, Sa'a hinou; loulou quick, Sa'a läuleu. Where in $\mathrm{Sa}^{\prime}$ a $a$ changes to $e$ in certain words after a preceding $i$ or $u$, no such change is made in Lau in the same words: $i a$ fish, Sa'a $i$ 'e; $u a$ still, Sa'a $u e$; $i$ asi at sea, Sa'a $i$ 'esi.

The diphthongs are $a e, a i, a o, a u, e i, o u$, as in sae, mai, rao, dau, mei, fou, pronounced, respectively, as in the English words eye, iron, hour, how, hey, oh.

The consonants are $f, k, g ; d, t ; b ; q, g w ; l, r ; s ; m, m w$; $n, n g$.

The $f$ replaces an $h$ in Sa'a: fera village, Sa'a hera courtyard; fuli fera village, Sa'a huli bed, huli nume site of house. The sound represented by $f$ often approximates to $v$.

Both $k$ and $g$ are hard. The Melanesian $g$ is not heard; as in $\mathrm{Sa}^{\prime} \mathrm{a}$, it has been dropped in certain words, $i a$ fish, but there is no noticeable break in the pronunciation. In certain other words this $g$ is replaced by $k$ : take, to stand. Mota sage, Sa'ata'e. The $g$ in Lau may replace a $k$ in $\mathrm{Sa}^{\prime} a$ : igera they, Sa'a ikire. A $g$ also appears in personal pronoun plural 1, excl., where Sa'a has a break: igami we, Sa'a $i^{\prime} e m i$. A $g$ may also replace an $h$ in Sa'a: luga to loose, Sa'a luhe.

There is no preface of $n$ in the sound of $d$.

In many words a $t$ has been dropped: angi to cry, Oceanic tangi; asi sea, Oceanic tasi; ola canoe, Florida tiola, Sa'a 'iola.

There is no $w$ in Lau. Where it occurs in Sa'a its place is supplied in Lau by $q$, the sound of which is $k w$ or $k u$ : qalu eight, Sa'a walu. In Lau the island Ulawa is known as Ulaqa. A $q$ in Lau may represent an $h$ in $\mathrm{Sa}^{\prime} a$ : qai, the 
reciprocal prefix, is in Sa'a häi. The letter gw may represent a $q$ (pw) in Sa'a: gwou head, Sa'a qäu; gwini wet, Sa'a qini; gwou deserted, Mota wou. The sound of $d$ is not followed by $r$, as is the case in Sa'a, nor is $d$ before $i$ sounded any way differently, as is the case in Sa'a. Nasal $m, i$.e., $m w$, is not so common a sound as it is in $\mathrm{Sa}^{\prime} \mathrm{a}$, but it is heard in mwane male, mwela child.

There is an interchange between $n$ and $l$ : nima or lima five; daluma middle, Sa'a dänume; inala to discern, Sa'a ilala. Both $l$ and $r$ are used and the sounds are distinct; both sounds are trilled.

\section{ARTICLES.}

(a) Demonstrative:

Singular, $n a$, si; ta, te, ke; maae;fe.

Plural, gi; mwai, ote.

(b) Personal: a, ni.

$N a$ denotes a, any, the, and is put to more general use than the corresponding nga in Sa'a; na is used with both singular and plural: na noni the body; na sasigamu your brethren. The conjunction $m a$ (=and) coalesces with $n a$; mana Mwela and the Son. $\mathrm{Na}$ is used with the interrogative taa what.

2. $S i$ is more definite and particular in meaning than $n a$ and denotes a part, a piece, any; it is more or less equivalent to me' $i$ in Sa'a: si doo ne the thing; gamelu ka ania si taa what are we to eat? si ere a firestick; si doo gu saea na that which I said; na may be prefixed: na si baea taa ne what words? si can not be used of the plural.

3. Ta means a certain one, every, at all, just, only, and is the same as the numeral $t a$ one: $t a$ may precede the article fe; ta fe uo every hill. ni may follow ta: tani aiai some, other. ta may mean only: ta ro ai only two people; ta may be used with the numerals, ta ro mwane two men; ta ro tangale penny 200 pence.

$T e$ has practically the same meanings as ta: te geni sarii a maiden; te taifilia he alone; te aiai falaete one person only. $T e$ is used of units (as ata in Sa'a), te fu fe doo only seven things; te ai ma te ai one by one; too te ai singly. Si may 
follow both $t a$ and te: ta si fou a certain rock, te si na doo everything; te may be used as equivalent to the conjunction and: te na Mwela and the Son.

$K e$ is used as te: ke si gula iidimani a small piece; ro kesi kurui bata two small pieces of money. $K e$ and si may be combined and used with te: e langi asia na teke si doo there is nothing at all.

4. Maae is compounded of maa eye, one, and $e$ the construct form, and means one, a; maae is used with fera country, dangi day, rodo night, oru wind; maae fera a village, maaedangi a day, maaerodo darkness.

5. Qe is used with certain nouns: qe afe a widow, qe ia a fish, qe oru a widow; na may be prefixed: $n a$ qe ia gi the fishes.

6. Fe is used of things spherical in shape and denotes a unit: fe bread a loaf, fe bubulu a star; also fe gale bola a young pigeon, fe rade a reed; $f e$ is used of one of a series: fe rodo a night, fe asua a day; fe is also used as a multiplicative: fe fiu ade doo taala seven cases of wrong-doing; na or ta or te may precede.

7. Gi denotes plurality and follows the noun: na mwane $g i$ the males. It may be separated from the noun: $n a$ doo nia $g i$ his things; $g i$ is used with the forms of the personal pronoun plural except those ending in $l u$.

8. Mwai is used with nouns of relationship only: mwai asi nia his brethren, ro mwai sasina brethren.

9. In Port Adam ote seems to be employed as a regular plural article: ote mwane gi you men. But it is a question whether ote is not properly employed of females only: ote aia nia his female relations, ote sasina his sisters, ote ai you women, ote ai gi you women.

10. $A$ is used as a personal article with the names of males, both native and foreign: $a$ Leo, $a J o e$. It is used also with doo thing: a doo so and so, a doo na the person.

$N i$ is used as a personal article with the names of females, both native and foreign: ni Alida, ni Mary. It is used also with certain nouns which denote women, where in Sa'a nga or the personal article $a$ is used: ni te nau my mother, ni mwaemwane a man's sister, a woman's brother, 
ni aia female relations, $n i$ doo the woman, ni mwela ne that woman. $N i$ is not used with afe wife, nor with geni female; it is not used with the plural.

\section{NOUNS.}

1. Nouns to which possessive suffixes may be added: Certain nouns take the suffixed pronoun denoting the possessor. These are nouns denoting:

a. Parts of the body: lima hand, limagu my hand, aba arm, abamu thy arm, maa eye, maamu thy eye.

$b$. Position, end, middle, top: buri behind, burigu behind me, $i$ dalumana in the midst, $i$ singana its end, $i$ kamena lobo beside the lake, $i$ fafona on top of it.

c. Certain states or doings of men: life, death, speech, custom, goings : mae to die, maela death, maelana his death, baela speech, baelagu my word.

$d$. The word sasi brother, sasigu my brother, my sister. The other words denoting relationship employ the personal pronoun to denote possession.

2. Formation of nouns: Nouns which have a special termination showing them to be nouns substantive are (a) verbal nouns and (b) independent nouns.

a. Verbal nouns are formed from verbs by the terminations $a, f a, l a, t a:$ mae to die, maea death or sickness, maela death, bae to speak, baea word, baela speech, fanga to eat, fangaa feast, food, fangala food, mae to die, maemaefa sickness, nao to lead, naofa first, naofe mwela eldest child, also with suffixed pronoun naofana mwela; $t a$ is seen in the root afuta all, which is used only with the suffixed pronoun, afutagera all of them, afutana na ai gi all the people. The termination $l a$ has a more or less gerundival force.

Compound nouns may be formed, girigiri lifoa gnashing of teeth, saitama dooa wisdom.

Where in the vocabulary $f a$ and $t a$ have a hyphen attached, it is intended to show that they are used only with the suffixed pronoun attached.

There are certain adjectives to which the termination $l a$ is attached, diena good, dienala goodness, baita big, baitala bigness, and tasa in excess, tasala excess. It is probable, however, that these words are really verbs. 
b. Independent nouns: The only termination is na, and this is added (1) to certain nouns which express relationship or kindred; (2) to cardinal numerals to form ordinals.

1. Nouns so formed are always preceded by a prefix which marks reciprocity of relationship or kindred, mwai, and by the numeral ro two; sasi brother, ro mwai sasina the two brothers, te mother, ro mwai telana wife and child.

2. Numerals: olu three, oluna third.

3. Construct form: To make a construct form the letter $e$ is added to the first of two nouns, toloe fera hill, fuli abae ai men's handiwork. When the first member ends in $a$ the ae sometimes contracts to $e$, fufue ai seed, aqale mwai ten baskets, but maae rodo, a night; also when the first noun ends in $o$ the oe is contracted to $e$ : abole ai a log, abolo a piece. This $e$ may be added to words which have not a distinct noun termination: naoe gula the chief place.

4. Genitive relation: The genitive relation of nouns one to another is effected by the use of the propositions $n i$ and $i$ : $n i$ is used mainly in construction: baea ni sugela deceitful words, gwai ni gwaila anointing oil; $n i$ expresses purpose: si gula ni lea inia a place for him to go to, rosuli ni manatai gami hear us in mercy. In certain words $l i$ replaces $n i$ : maalimaea enemy, maalitafa a channel in a reef; $i$ is used also to denote purpose: lea $i$ fasifa came to sell it. Location, which also denotes place whence, is shown by $i$, geni $i S a a$, a Sa'a woman. Si is used in certain phrases: ofu si doo bundles, ro tooni si doo two thousand.

The genitive is frequently omitted olu teu flour, three measures of flour, mumudi fangala crumbs of food, mwane Saa, a Sa'a man, falisi vine a vineyard.

The possessive ana may be used to denote the genitive: luma ana foaa house of prayer, tala ana fanualama way of peace. A genitive relation is also shown by the use of the suffixed pronoun of the third person singular or plural in agreement with the idea expressed in the second noun of the pair: $i$ tolona fera on the tops of the hills, gwouda na ai gi men's heads.

The ordinary personal pronouns are used as possessive in cases where the pronoun can not be suffixed: afe nau my wife, arai nia her husband. 
The instrumental prefix $i$ occurs: kamu to eat areca nut, ikamu a line spatula.

5. Plural: To show plurality $g i$ is used, following the noun na mwane gi the men. The word oro, many, may be attached: na mwane oro gi many men, tani ai oro many people.

The personal pronoun plural third gera is used to mark plurality: gera fiolo the hungry, gera priest da adea urina the priests acted thus.

Totally and completion are shown by sui finished or sui na: afutada sui they all, gera lea sui na they have gone already. To express totality the suffixed pronoun singular third and all persons plural are added to a root afuta, formed from $a f u$ to complete, with $t a$ noun termination: afutana fera all the land, afutana nonigu all my whole body.

It is a question whether the numeral qalu eight is used like walu in $\mathrm{Sa}^{\prime} \mathrm{a}$ of an indefinite number, e. g., qalu fera all lands; but te si na fera seems to be the proper usage.

6. Gender: There is no grammatical gender. The words mwane male, geni female, are added when the noun does not carry a sex distinction.

7. Nouns of relationship: With the exception of sasi brother, sister, nouns of relationship are never used with a suffixed pronoun: maa nau my father. The prefix mwai, denoting reciprocity of relationship, may precede: mwai asi nau brethren. In speaking of pairs of people ro is used: ro mwai sasina two brothers. The na of sasina, telana, etc., is a noun termination and is not the suffixed pronoun.

The articles $n i$ for the singular and ote for the plural are used of women: ni aia a female relation, ote geni women.

The word for father is maa; the article $n a$ may be prefixed: na maa nau my father. The Rev. A. I. Hopkins says that maaka nau is also commonly used as meaning my father. The word for child is mwela, mwela na ai Soand-So's son, mwela nia his child; aia is used for female relations with $n i$ as singular article and ote as plural: mwaemwane sister, ni mwaemwane a man's sister. 
The adjective gale little, is used preceding the noun to describe something young: ro fe gale bola two young pigeons. The article used with te, mother, is ni: ni te nau my mother; ta ro mwai telana nau my wife and child, ta ro mwai fungona two relations-at-law; ai person, man, is used as a vocative: mwela ai hey, you there! na ai oe your people, ai ni raoa a servant, ai tou the little one, the lesser.

PRONOUNS.

The pronouns may be classified as (A) those used as the subject of a verb; (B) those suffixed to a verb or a preposition as object; (c) those suffixed to nouns substantive and denoting possession.

A. Pronouns Used as the Subject of a Verb.

Singular:

(1) inau, nau, gu.

(2) ioe, oe, o.

(3) inia, nia, ni, e.

Plural:

Inclusive: (1) igia, gia; igolu, golu.

Exclusive: (1) igami, gami, mi; igamelu, gamelu.

(2) igamu, gamu; igamolu, gamolu.

(3) igera, gera, da; idalu, dalu.

Dual:

Inclusive: (1) igoro, goro.

Exclusive: (1) igamere, gamere.

(2) igamoro, gamoro.

(3) idaro, daro.

1. The longer forms, those with $i$, are used as possessive pronouns when the suffixed pronoun can not be added: geni inau my wife.

The forms with $i$ are never used by themselves as the subject, but are accompanied by one of the shorter forms: igera da ada ma da si ada na they see but do not see. The three longer forms in the singular are of more or less infrequent use. The initial $i$ is run on to the preceding vowel in pronunciation.

2. All the forms without $i$ are used alone as the subject of the verb. Where there are three forms the second and third are generally used together as subjects: gami mi 
langi si saetamana we do not know; but the short forms $g u, o, m i, m u, d a$, may be used alone as subjects: gu si saea I do not know. The forms in $l u$ are not used as a trial number, but denote a more restricted number of persons.

3. Nia is used as meaning, there is, it is: efita fe bread nia agamolu, how many loaves have you? It may be used before a proper name as the equivalent to a genitive: ana maaedangi nia Abiathar in the days of Abiathar.' When the meaning is, there is, it is, nia is preceded by $e$ : na liqa gera enia ada they have their holes; ma te ai enia $i$ luma there is only one person in the house; with na demonstrative added: nia na that is it, that is so.

4. The form $n i$ is seen in nifai what? where? It occurs in certain phrases as meaning, it is, there is: $e$ uta ro si lio ni agamu how is it ye are of two minds? na light fuana noni ni maa the light of the body it is the eye.

5. The plural sign $g i$ is used with the forms in the plural but not with those ending in lu: gia gi fi dao na we have just come.

6. The forms in the plural third igera and gera are used as equivalent to a plural article: igera na judea the Jews.

7. The pronouns of the third person singular and plural may be used of impersonal or inanimate things.

B. Pronouns Suffixed to Verbs or to Prepositions as Object.

Singular: (1) nau. (2) oe. (3) a.

Plural:

Inclusive: (1) gia, golu.

Exclusive: (1) gami, gamelu. (2) gamu, gamolu. (3) gera, da, dalu.

Dual:

Inclusive: (1) goro.

Exclusive: (1) gamere. (2) gamoro. (3) daro.

1. Examples of usage are, gera saegera sui they were all summoned, nia lea fonosia he went to get it. A second object of the verb always appears in the suffixed pronoun singular and plural third: gu langi si adasia na ola I did 
not see a canoe, gera gutafigera na mwane gi they persecuted the men. All prepositions governing nouns have the pronoun suffixed as an anticipatory object in agreement with the noun: gera lea fonosia fera they went to harm the land, fafia si doo concerning the matter.

2. The verb dori (to wish) has the pronoun suffixed where in $\mathrm{Sa}^{6}$ a none would be used: nia langi si doria gwou ana he would not drink (it) of it.

3. To taifili (alone) the pronouns are suffixed: te taifilia he alone, taifiligera they alone.

C. Pronouns Suffixed to Nouns or to Verbal Nouns used as PRE POSITIONS.

Singular: (1) gu. (2) mu. (3) na.

Plural:

Inclusive: (1) gia, golu.

Exclusive: (1) gami, gamelu. (2) gamu, gamolu. (3) gera, da, dalu.

Dual:

Inclusive: (1) goro.

Exclusive: (1) gamere. (2) gamoro. (3) daro.

1. These are the pronouns denoting possession and they are suffixed to a certain class of nouns only, those which denote names of parts of the body, or of family relationship, or of things in close relationship to the possessor. In all other cases possession is denoted by the use of the ordinary personal pronouns.

2. When things and not persons are in question $n i$ is used in place of $d a$ in plural third: lea alua i fulini go and put them in their places.

3. Of the plural forms those ending in $l u$ denote a restriction in the number of the persons concerned.

4. These pronouns are also suffixed to the preposition fua to, used as a dative, to afuta all, and to certain other words which show a noun termination but which have no independent existence as nouns: otofa concerning, oofa approaching to, enceinte, sie, at the house of (in the vocabulary all such words are followed by a hyphen); also to mara of one's own accord, alone, te taifilia marana he alone; also to the verb too to hit, toogu, toona, hit me, etc. 


\section{Demonstrative Pronouns.}

These are $n a, n e$, this; nena, nana, nane, that.

1. These all follow a noun or a pronoun: a mwela ne this person, nia nana that is it.

2. $N a$ is added after the negative langi: langi na no, not that; and after sui finished: sui na that is finished.

3. Go an adverb, there, is used as a demonstrative: tefe doo go ana only one thing, inau go agu I for my part; ne may be added, gone that, inia gone that is so. $B a$ means that, there: diena ba good! bago is used following a noun or a pronoun: a doo bago that person there.

\section{Interrogative Pronouns.}

1. The words used are ati, who; taa, tafa, what. The personal article $a$ makes ati who, singular, gerati plural. Both $t i$ and taa are nouns. The adverb $b a$ may be added to ati for the purpose of emphasis: ati $b a$ who? $T i$ stands for the name of the person and ati means, what is the name? ati mwane what man? The demonstrative ne may be added for emphasis: ati ne who is it then? Ati has also an indefinite use: ati susulia who knows?

2. With taa, tafa, the definite article si may be used: si taa what, that which. taa may follow the noun, ta si doo taa what sort of thing? si doo taa ne what? The adverb fai (where) may be used as an interrogative pronoun: ni fai which, what?

\section{Indefinite Pronouns.}

The uses of $t a, t e$, have been dealt with under "articles." These two words are used as signifying, any, some, other.

The noun sai place, thing, has an indefinite use: sai ai that which, what, sai na that which, ta sai ai, one, another (of things), sai oe your place, your duty, tani oto ni sai ai some people. (The Rev. A. I. Hopkins states in a note that sai in Lau is used of food only).

\section{Relative Pronouns.}

There are no relative pronouns. Their place is supplied by various locutions. 
1. By the suffixed pronoun: inia nane gu bae kekerofana fasi uri this is he of whom I spoke. The addition of the demonstrative ne, nena, serves to make the meaning clearer: inia nena ai gami mi maasia he is the person for whom we are waiting.

2. By making use of a coördinate clause: igami ne too gera ada fuada na we are the people whom they have chosen.

\section{Possessives.}

Singular: (1) agu. (2) amu. (3) ana.

Plural:

Inclusive: (1) aga, agolu.

Exclusive: (1) agami, agamelu. (2) agamu, agamolu. (3) agera, ada, adalu.

Dual:
Inclusive:
(1) agoro.
Exclusive:
(1) agamere.
(2) agamoro.
(3) adaro.

The possessive is used:

1. Of things to eat and drink: si fangala agu something for me to eat, o ngalia amu take it for your eating, si doo ana gera priest tafiligera food for the priests only.

When the sense relates to food in general and not to a particular meal the ordinary personal pronouns are employed as possessives: si doo ni gwou inau a drink for me.

2. As meaning, for me, for my part, etc., belonging to, at, with: geni agu a wife for me, nia lea ana he went his way, gu ka gele dau go agu if I but touch, fuana ngalia fera nia agolu to get his land for ourselves, si mamana nia ana power in himself, his power, si doo oro agu I have many things, e langi ana not in it, lost, nia soe agera he questioned them, soea satana ana a doo bago ask so-and-so his name, nia ledia tasi doo agu he asked me about something, ooganga agera their debt.

3 . As the object of a neuter verb (i. e., a verb which does not take a transitive suffix): gera da qele ana they marvelled at him, gu ingo amu I beseech thee, dau agu touch me, bota ana blessed is he. 
4. With verbs when the object is separated from the verb: nia bubu tete adalu he regarded them fixedly, $k a$ lugatai saufini ana let him go secretly, da bae aisile ana they spoke scornfully of him: ala meme gamu to bite and rend you, is a variant.

5. To express, of, from, among: ati mwane agamu what man of you?

6. The forms ending in $l u$ denote a restriction in the number of the people concerned.

7. The adverb afoa apart is also followed by the possessive: afoa ana apart from him.

8. It will be seen that the one possessive in Lau does the work of the three that are used in Sa'a. A Port Adam man asking for a wife at $\mathrm{Sa}^{\prime} \mathrm{a}$ and saying geni ana (as has happened at times) would be asked whether he wanted to eat her-the Sa'a use being keni nana, 'ana being reserved of things to eat.

\section{ADJECTIVES.}

1. Words which are qualifying terms may also be used in the form of verbs, but some may be used without verbal particles and follow the qualified word. Mwane baita a big man, mwela tou a little child.

2. Some words have a form which is used only of adjectives, either of termination or of prefix.

$a$. Adjectival terminations are: $a, l a$.

The termination $a$ is suffixed to substantives and verbs: rodo night, rorodoa dark, darkness, cloud; bulu to be black, bubulua black.

$L a$ is suffixed to substantives and verbs: mwai a bag, mwaila rich, kobu to be fat, kobukobula fat, whole, big; tagalo to be wandering, tagalola matted, thick, of forest.

$b$. Adjectival prefixes are $a, m a, t a t a, m$. These are all prefixed to verbs.

The $a$ is prefixed to verbs to form participles: luga to loose, aluga loose; la to lift up, alaa upwards, up.

$M a$ denotes condition: lingi to pour, malingi spilled, $n g i$ to divide, mangisingisi broken, divided, matala only, merely; tefe mwela matala an only child. 
Tata denotes spontaneity: tatagwelu headlong.

$M$ as a prefix appears to be used in the word moi broken, (Sa'a 'o' $i$ to break, ma'o' $i$ broken).

3. Comparison: Degrees of comparison are shown by the use of prepositions or adverbs, or by a simple positive statement. The prepositions used are fasi from, tasa beyond, in excess. The suffixed pronoun is used with fasi, but the possessive is used with tasa: na boso nia baita fasia na asufe a pig is larger than a rat; gera baita tasa agera these are much larger than those.

The adverbs employed are gele little, somewhat, asia very, too much: nia baita asia it is very (too) large.

A positive statement carries comparison by implication: doo ne nia baita that is biggest, sai ai ne ni diena, sai ai nena ni taa na this is good, that is bad; $i$. e., this is better than that.

\section{VERBS.}

Almost any word may be used as a verb by prefixing the verbal particles, but some words are naturally verbs as being the names of actions and not of things. There are also verbs which have special forms as such by means of a prefix or termination. Verbal particles precede the verb; they have a temporal force.

1. The verbal particles are $k a, k o$. The particles are written apart from the verb, but the speakers like to join them to the governing pronouns of the first and second persons singular, $g u, o$.

$K a$ is used both of present and of future time: nia ka bae uri he speaks thus, ka urina if that be so, tasi doo taa gera ka adea what will they do? lelea ka rodo go till nightfall; the illatives $f, f e$, may be added.

$K_{0}$ is used only with the personal pronoun, second singular 0 , and may express either present or future time: the illative may be added.

The preposition fuana to him, to it, in order that, is used as a subjunctive or optative.

2. Time and Moods: A subjunctive is formed by ana if, when, followed by the particle $k a$, or by the use of saea.

Conditional affirmation is expressed by saumala. 
The illatives are $f$ and $f e$, and mean, then, in that case, following upon, just now, for the first time: ta ka fi uri then said he, gami mifi saitamana na tala uta and how shall we know the way?

$F e$ as an illative denotes, in that case, following upon; $f e$ is also used like $h \ddot{a} ' i$ in Sa'a, to denote repetition or continuance or restoration: na abana e fe boeboela lau his hand was restored whole again, gera ka fe dao toona they will certainly reach him, daro fe lea lau go they went on again, da tefe bae ana tesi baela they all cried out together.

$N a$ is used following the verb to form a preterit: nia mae na he is dead. Finality is shown by the use of sui: sui na it is all finished, nia kafi dao sui na when he shall have arrived, sui nana it is finished, sui ta thereupon, after that.

For the imperative the simple verb is used: o lea amu go away; fasi may be added for politeness: lea fasi amu you go!

3. Negative Particles: The foregoing particles are not used in negative sentences. The negative particles are langi, e langi, si. These may be combined: nia langi si saea he does not know it, e langi mu si rongoa ma e langi $m u$ si saea you have neither heard it nor seen it, e langi nau gu si lea I am not going, e langi uri ta ai e adasia no one has seen it, e langi asia not at all. The verbal particle $k a$ may be used in negative sentences with the addition of si, kasi bobola it is not fitting. The dehortative and the negative imperative is fasia: fasia oko lea do not go! fasia gera ka adasia let them not see it, o fasia oko luia do not forbid it.

Genitives: $n i, i$ are used to express purpose.

4. Suffixes to verbs: There are certain terminations which, when added to neuter verbs or to verbs active only in a general way, make them definitely transitive or determine their action upon some object. These are of two forms:

a. A consonant with $i: f, l i, m i, n i, n g i, s i$, or $i$ by itself; e.g., tau, tauf; mae, maeli: ano, anomi; mou, mouni; 
sau, saungi; ada, adasi; manata, manatai; to the verb taa to be bad, both si and $l i$ are added and the causative fais prefixed:fataasi, fataali, to make worse. Certain verbs which are active in Lau are neuter in $\mathrm{Sa}^{\prime} \mathrm{a}$ : angai to lift, angaia lift it, Sa'a angainia; faodo to straighten, faodoa straighten it, Sa'a ha'aodohie; famae to kill, famaea, Sa'a ha'amaesie; famou to frighten, famoua, Sa'a ha'ama'usie.

$b$. The termination $a i$ is suffixed by itself to nouns to convert them into verbs, sato, satoai. When this syllable $a i$ is suffixed to verbs the genitive $n i$ may be added, and to the form aini the consonants $f, m, n g, t$, are prefixed: oli to return, olifaini to carry back, ala to answer, alamaini to consent, sau to become, saungaini to make, tagala lost, tagalangaini to drive out, foaa to pray, foaataini to pray for. The forms in ai are also used intransitively: tege to fall, tegelai lost, oli to turn, olitai converted.

The genitive $n i$ (cf. M. L., p. 532) is often omitted and is not invariably used as it is in Sa'a, since the form ai without the addition of $n i$ is transitive: gonitai to receive, gwoutai or gwoutaini to be left alone, oalangai to apportion, fatolamai to command.

$A n i$ appears to be used by itself as a transitive suffix: ui to throw, uiani to throw away, laga to drive, lagaani to ${ }^{\circ}$ drive away, taba to strike, tabaani to destroy; ani is used also with too to hit, tooani to understand.

With either class of suffixes there is no difference in meaning between one suffix and another.

5. Prefixes to verbs: These are causative and reciprocal.

The causative is $f a$ : it may be prefixed to almost any word, and it may be used with words which have a transitive suffix. The use of $f a$ frequently obviates the use of a transitive suffix and of itself makes verbs transitive.

The reciprocal is qai: generally when qai is prefixed to a verb the action of the verb is enlarged and the subject is included. The illative $f e$ also marks repetition or restoration or continuance; it is followed by the adverb lau again: na abana e fe boeboela lau his hand was restored whole.

6. Passive: The passive is expressed by the use of the personal pronoun plural third gera or $d a$, with the verb 
and the adverb na already: gera taufia na it has been washed; gera and $d a$ are used impersonally. The word saetana it is said, sae to say, is used as a passive: si doo saetana the thing said, si baela ne saetana uri the word which was said.

7. Auxiliary verbs: alu to put, is used as meaning, to be, to become; talae, v. tr. to begin, means also to become; sau to make, with the possessive ana, sau ana to become.

8. Reflexive verb: The word mara with suffixed pronoun is used to denote reflexive action: nia suungia marana. It also carries the meaning self, of one's own accord: $i b o-$ bongi ka manata tetea ana marana the morrow can take care of itself.

9. Reduplication: Verbs are reduplicated in two ways: (a) by reduplication of the first syllable: liu, liliu; bae, babae; (b) by repetition of the whole word: gwou, gwougwou. There is no difference between the various forms beyond an intensification in meaning. In the vocabulary the reduplicated form is presented under the entry of the stem.

\section{ADVERBS.}

There are pure adverbs in Lau, but many words used as adverbs are truly nouns and others are verbs; adjectives may also occur in this employment.

1. Adverbs of place: mai here, hither; go there, thither, ne may be added, gone, also langi go, no. lo there, is compounded with go and gi, logo north, west; se here, a noun, $i$ se, isena, here, in this place. gula place, a noun: si gula na this place, here, gula $i$ maa outside. balı side, a noun, bali ne here, on this side; $i$ bali Jordan $i$ bali logo on the far side of Jordan; ifai where, gamu mai ifai whence are you? tau, a verb, far off: alaa up, south, east, ilangi, ifafo, up.

2. Adverbs of time: kada na (ne), manga na, now; si manga, kademanga, when, i kademanga na (ne), at the time when; $i$ angita, si manga uta, when? inao of old, in the past; ua mai inao from of old; isingana ne henceforth: alua fasi, taraina, presently; urii just now; lau, lau go, again; oli back; na, ua na, already: ua yet, still, still left; ua go 
$i$ uarodo while still dark in the early morning; ua mai an a lua from the flood, toongi ua inao old clothes, e langi ua not yet, still wanting; firi, tefou, always; too ka tau forever; suli dangifiri daily; taraina to-day; $i$ rogi yesterday; maaedangi $i$ fafo day before yesterday; bobongi to-morrow; taraina lao rodo to-night; talae first; loulou quick; aliali forthwith; maasia, kade manga, while.

3. Adverbs of manner: alafana as, like, as if; uri, uria, sae, saea, that (of quotation); uri, urina, thus; e uta how? gele somewhat; asia completely, too much; saumala granted that; falaete, mamaloni, only; ooni merely; talai for no reason; tefou together; afui altogether (precedes verb); boro, oto, otomone, tamone, bota ana, perhaps; mone gives life, $b a$ gives force, to the narrative; $b a$ also explains and makes the diction less abrupt; tasa, tasaana, too much; faoroa often.

\section{PREPOSITIONS.}

\section{Simple Prepositions.}

Locative, $i$. Dative, fua.

Motion to, fua, isuli, suli. Instrumental, ana, ani.

Motion from, fasi, ita. Relation, ana, ani, fai, sia, usi.

Causation, fafi.

Position, fonosi.

Genitive, $n i, i$.

The locative $i$ is seen in $i f a i$ where; it is also largely used with adverbs of place and time and it precedes every name of place. With the exception of the locative, the instrumental, the genitive, and also ana, ita, usi, all the foregoing prepositions are used with a suffixed pronoun; ita is used with the possessive.

Isuli denotes motion after, motion over: sulia rodo ma na asua day and night, manata suli to know.

Fafi means, about, concerning, because of, around, on: gera ogu fafia they crowded round him, nia alua abana fafia he laid his hand on him, lau fafi to rescue, fafi taa what about, why; fuana in order that, mae fuana to die to his disadvantage, soe ledia fuana question him about it, bae fuana forbid him, fuana taa wherefore?

Of the two instrumental prepositions ana is the one in more general use, its meaning is with: doo gera saungia 
ana the thing they killed him with. Ana appears to denote the actual instrument, ani the method of action; ani may be translated withal. When the noun denoting the instrument is not preceded by an article or when the noun is used in a general sense, ani is used in the place of ana: suu fafia ani taa to clothe himself with what? lea ani ola to go by canoe.

The pronoun a may be suffixed to ani: tasi doo gera qaifamanatai ania the thing they taught withal; ka modea na toongi ua inao ania to mend the old garment withal.

Ana also denotes at, in, place where, among: luma ana foaa (luma ni foaa) a house of prayer, kakao ana ano an earthen vessel, nia liu ana ta maaedangi he went on a certain day, tani ai ana aigi some of the people, nia saea ana satana he called him by his name, o ngalia ana ati from whom did you get it? lea ana fera to go into the country. ani is used as meaning in, e langi ani nau there is nothing in me, gera ote gera ani nau they will have nothing to do with me.

Fai means with: faioe with thee, qaimani fai to help, oko qaimani fainau you help me. The genitive ni may be added, lea fainia go with him; fainia moreover, and.

Sia means at, at home, and always has the suffixed pronoun. By the ordinary Melanesian idiom place at comes to be used of motion to: siagamelu chez nous, siena ere beside the fire, lea mai siegu come here to me. Usi means over, on behalf of, for: gera ngisu usia they spat on him, na captain usia na too a captain over the people, na taba olisia usia na aigi a redemption for the people.

The genitives have been dealt with under nouns: $i$ is in most general use, both are used to express purpose, and ni also denotes for, belonging to: fasia muka manata ni bae uri think not to say thus, gera mou ni oli they feared to return, $k$ a ote nia ni rosuli he is tired of obeying.

\section{Compound Prepositions.}

Some of these are nouns used with the locative; the pronoun is suffixed as the actual object or as the anticipatory object when a noun follows: $i$ fafo above, $i$ fara 
beneath, $i$ lao within. The locative need not be used with lao: lao rodo in the night, lao tala in the path, lao salo in the sky. Some are constructed from verbal nouns to which the suffixed pronoun is always added: fonosia in front of him, nia initoo fonosi gera he ruled over them, fonosi taa to meet what? for what purpose? Certain verbs are used as prepositions: maasi to await, garangi to be near.

\section{CONJUNCTIONS.}

Copulative, $m a$.

Adversative, $t a$, $m a$ ta

Connective, $t a$.
Disjunctive, langi, langi ta, ma langi, ma ka langi.

Conditional, ana, ma ana, saea. Illative, $f i, f e$.

A mark of quotation is saea, uri. Neither, nor, is expressed by a negative followed by ma. Until is dao ana, lea dao ana.

\section{NUMERALS.}

The numerical system is decimal. All numbers over the tens are expressed in tens.

\section{Cardinals.}
1. eta, ta, te.
6. e ono.
2. e rua, ro.
7. e qalu.
3. e olu.
8. $e$ fiu.
4. e fai.
9. e siqa.
5. e lima.
10. e tangafulu, aqala.

In numbers other than eta the initial $e$ is omitted in quick counting. In composition one is ta, two is ro, te generally means only: rua is reduplicated into ruarua, tau ruarua equidistant.

The prefix too forms distributives: too ro doo two things at a time. Nima is used as well as lima for five. Though qalu eight, appears in the translations as used of an indefinite number it is doubtful whether such use is correct. Tangafulu is the tenth of a series; aqala is used for ten denoting a unit, aqala fono a full ten.

To express units above ten mana is employed: aqala mana fai fourteen. 
One hundred is tangalau: tangale doo one hundred things. The sum above the hundred is expressed by mana: tangalau fai aqala mana fai one hundred and forty-four. One thousand is too.

\section{Ordinals.}

The cardinals with a substantival ending $n a$ form ordinals.

First, etana.

Second, ruana. Third, oluna.
Fourth, faina.

Fifth, limana.

Sixth, onona.
Seventh, fiuna.

Eighth, qaluna.

Ninth, siqana.

Ordinals precede the noun: ruana na mwane the second man.

Ordinals are used to express the number of times: $e$ ruana lau nia lea go he went away the second time.

Ruana also means fellow: na ruana gera their fellows.

Tenth is expressed by tangafulu ana: aqala maaedangi mana ruana the twelfth day, tangalau ro aqala mana etana one hundred and twenty-first.

Efita how many, is used with the substantival termination na: efitana what number?

\section{Multiplicatives.}

The article $f e$ is employed to form multiplicatives: guka fai fe olila I shall return four times, sasigu ka fita fe ade doo taala fuagu how often shall my brother harm me? tafe once.

The causative $f a$ does not make multiplicatives except in the case of faoroa often.

\section{EXCLAMATIONS.}

Iu, iuka, assent. Oto mone is that so? $\mathrm{Ne}$ is used in questions, ati ne satamu what is your name? na mwela a Joseph e langi ne Is He not the son of Joseph? Aia sums up, so there, well then! Oimae alas! The noun $a i$, person, is added to proper names to call attention, Joe ai hey, Joe! 


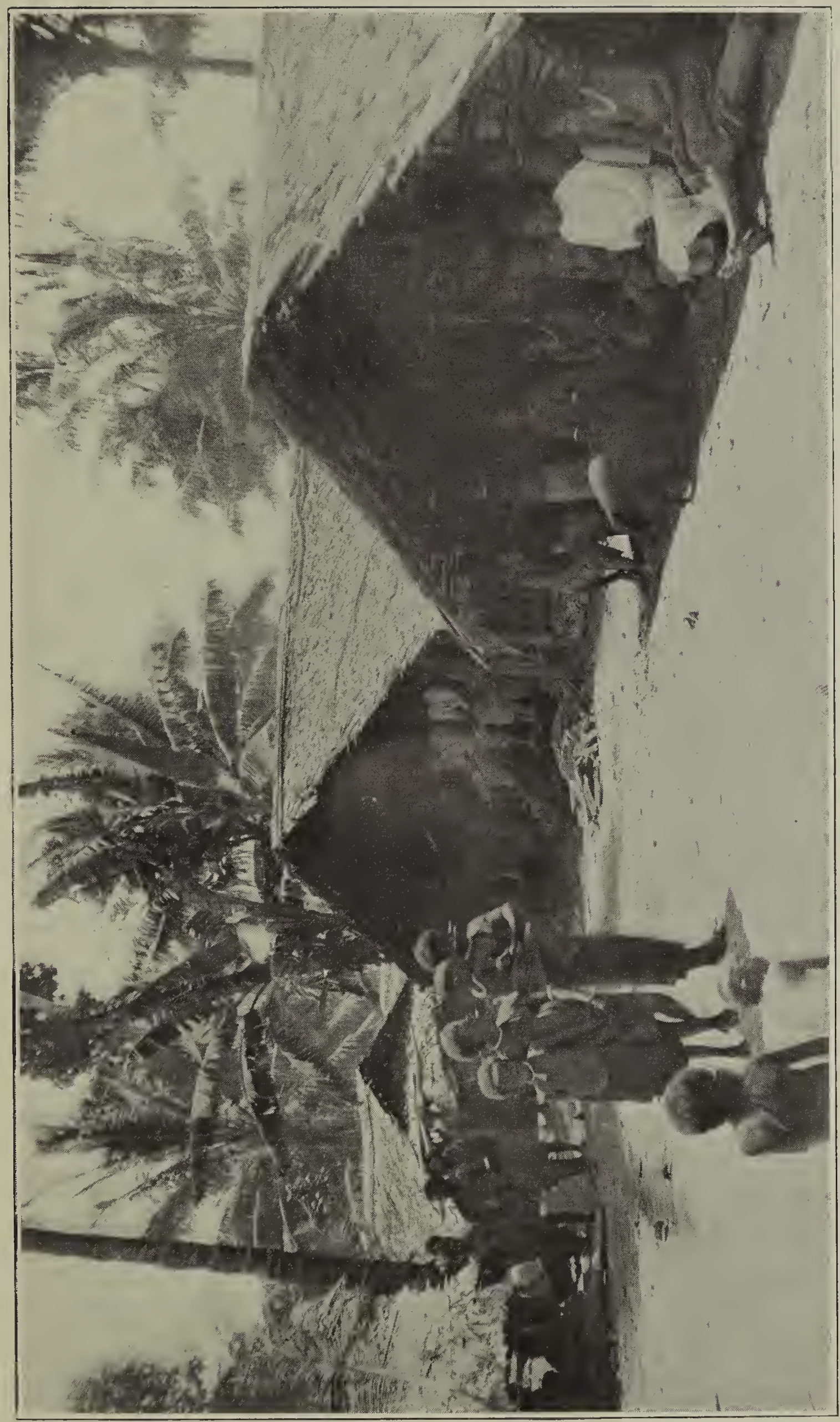

בే 



\section{LAU VOCABULARY.}

A.

a 1, personal article: used with the names of males, both native and foreign, a Masuraa, a Luke; is used also with doo, thing, a doo So-and-So, a doo na, the person; is seen also in at $i$ who? In usage it corresponds to the $i$ of Mota and Malagasy. Cf. S. $a$.

a 2, termination of the verbal noun: attached to verb, angi to cry, angia a cry, fanga to eat, fangaa a feast; added to compounds girigiri lifoa, gnashing of teeth.

a 3, pers. pron. sing. 3. suffixed to verbs as object, and to prepositions as anticipatory object and used both of persons and things: him, her, it. S. $a$.

a 4, stem to which the pronouns $g u, m u, n a$, etc. are suffixed in forming the possessive. S. $a$.

a 5, prefix of condition making participles: luga to loose, aluga loosened. S. 'a.

a 6 , adj. term. suffixed to nouns and verbs rodo, night, rorodoa, belonging to darkness, bulu, to be black, bubulua, black. S. 'ä.

a 7 , exclam. negative; don't!

aba (gu) n., hand, arm, part, leaf: fuli abae ai, men's handiwork. S. 'apa.

abaa n., staff. S. apaa.

abalolo a banyan tree. S. 'apalolo.

abasua adj. afraid of, silent out of respect for a person.

abatoo v. i. to be barren, of women.

abolo n., a piece: abole ai, a beam. S. polo.

abu (gu) n., blood: abu rakaraka, an issue of blood. S. 'apu.

abua adj., red.

abu 2. v. i. to be forbidden, taboo: abu rongo, to be unwilling to hear. S.'apu.

abulo partic., turned round: abulo fasi, to face towards.

abuloa v. n. a turning round. S. apulo.

abusu v. i. to be filled, satiated.

abusua v. n. satiety.

ada 1. v. i. to see, to awake.

ada filo to perceive; ada fua, to choose; ada sae tamana, to rec-

ognize; ada too, to succeed in finding.

adala, v. n. sight, seeing.

adasi, v. tr. to see. faada.

ada 2. poss. pl. 3, among them, for them, for their part, theirs (of things to eat), used also as obj. to neut. verb; tani aiai ada. some of them. S. 'ada.

Adagege artificial islet next to Ferasubua going north.

adalu poss. pl. 3 , as $a d a$, but more restricted in application.

adaro poss. dual. 3. Cf. ada 2 . 
ade v. tr. to do, to make; of disease, to be prostrated by si maea $e$ adea, he was sick; ade au, to play on a bamboo flute; ade doo, to worship; ade doola, worship.

adi $v$. tr. to taboo, to place one's mark upon, S. ädi.

ado, adomi, v. tr. to serve, to wait upon, to furnish with food, to worship.

ae (gu) 1. n. foot, leg; lado ae, to follow; aena, because of, aena falisi, lord of the garden; ae i fera, a householder; ae mwane, chief man. S. 'ae.

ae 2. exclam. ah! ; used also in summing up.

afa 1 . v. i. to cut, to incise, to mark by cutting. S. aha.

afa 2. an eagle. S. hada.

afe 1. woman, wife; si afe nau, my wife.

afe 2 . v. tr. to direct, to guide, S. 'ahe.

afe, afeafe 3. n. foam, waves; na afe, surf. S. ahe.

afedali; matai afedali, to be in a fever. S. madali, wet with perspiration.

afetai partic., difficult; bae afetai, to take an oath.

afoa partic. apart, separate. S. ahoa.

afu v. tr. to wrap up, to hide. S. ähu.

afui partic. precedes verb, altogether. S. ahu'i 4 .

afuta- (gu) n. all; afutana, all of it; afutagamere, both of us. S. ahuta. aga poss. pl. 1. among us, for us, for our part, ours (of things to eat), used also as obj. with neuter verbs. S. aka.

agalimae a spirit, a ghost.

agalo a ghost; qaife agalo, a witch doctor. S. 'akalo.

agamelu poss. pl. 1. excl. for us, for our part, among us, us (obj).

agamere poss. dual, excl. for us two, among us two, us two (obj.)

agamolu poss. pl. 2. for you, among you, you (obj.)

agamere poss. dual, excl. for us two, among us two, us two (obj).

agamolu poss. pl. 2. for you, among you, you (obj).

agamu poss. pl. 2. for you, among you, for your part, you (obj.); ati mwane agamu, what man among you?

agani v. tr. to pluck out. S. akani.

agau to be ready. S. akau.

age; age reresi, a lily. Crinum asiaticum.

agera poss. pl. 3. for them, among them, them (obj.).

ago, agoago, 1. v. i. to be hot, to shrivel up; manata agoago, to be zealous; 2 . n. si agoago heat.

agofi v. tr. to cause to be hot.

agolu poss. pl. 1. more restricted in meaning than aga.

agoro poss. dual. 1. incl. for us two, of us two, us two (obj.).

agu poss. sing. 1. for me, for my part, me (obj.).

ai, aiai, 1. n. a person, kindred, you (voc.) Joe, ai, I say, Joe! mwela $a i, \mathrm{Hey}$, you! ai ana fera nau, my neighbour; ai salaa, a stranger; James ai tou, James the Less; ogule ai, a company; too te ai, a few; te ai gone, only one, aiai is used as a relative 
pronoun, the one, that, or as a plural, tani aiai, everybody; tani fufue aiai, some seeds. Compounded with sai; saiai ne, that which. Mota gai.

ai 2 . n. a tree; ai rarafolo, a cross. S. äi.

ai 3. ai lado, to graft.

ai 4. trans. suffix to verb; sato, satoai.

aia 1. sister, female relations; used with art. ni for sing., ote for pl.

aia 2. exclam. Hey! well then!

aini trans. suffix to verb. S. aini.

ainitalongaini $\mathrm{v}$. tr. to proclaim. S. talonga'ini.

ala 1. v. i. to answer; alagwau, to nod the head in affirmation.

alamai v. i. to answer.

alamaini $\mathrm{v}$. tr. to obey, to take notice of. S. ala.

ala 2. v. tr. to bite; ala meme, to bite and rend; ala tagalaa, to feed promiscuously (of animals). S. ala.

ala, alaala 3. v. i. to set a net; ala fafi, to surround, to catch.

alasi v. tr. to lie in wait for. S. ala.

alaa adv. up; of direction, southeast S. 'ala'a.

alafana adv. like, just as. Cf. S. alihana.

alange; alange gwou, to nod the head in affirmation. ala. 1.

aliali forthwith.

aliburi (na) v. tr. to shorten, curtail.

alida $v$. i. to journey by sea. S. älide.

alidea $v . n$.

alifii v. tr. to lament.

alifooa $\mathrm{n}$. blood money.

alinga $(\mathrm{gu}) \mathrm{n}$. ear; alinga bungu, deaf. S. 'älinge.

alitafu n. a dung heap, refuse. S. älitehu.

alofi v.tr. to shake off.

alu v. tr. to put, bury; v. i. to become; alu ere ana, to burn; alu mwela, to have children; salo e alu maraqai, the sky is red; alu fafola, addition, increase. U. 'alu.

alua, dehortative, no! don't! alua fasi, wait a while!

alula v. n. putting, becoming.

alualu v. i. bae alualu, to promise.

aluga partic. unloosed. luga.

amu 1. poss. sing. 2. for thee, thee (obj). gera soea amu, they asked it of thee. S. amu.

amu 2. vi. to be dumb; a amu, the deaf mute. S. amumu.

ana 1. poss. sing. 3. for him, her, it; used also as obj. e soea ana, he asked him for it; e lea ana, he went on his way; e ita ana mai, from there; qaifamanatai ana too, a teacher of the people; $e$ baita tasaana, bigger than it; bota ana, perhaps. S. ana.

ana 2. instrumental, with, therewithal; doo gera saungia ana, the thing they killed him with. S. ana.

ana 3 . belonging to, from, him, her, it; o ngalia ana ati, from whom did you get it? tani ai ana aigi, some of the people. S. ana. 
ana 4. time when; ana ta maedangi, on a certain day; ana koburo, in the time of the northwest wind, summer. S. ana.

ana 5 . after, by the name of; e saea lau ana satana, he called him by his name. S. ana.

ana 6. of, belonging to; used in composition; kakao ana ano, an earthen vessel; lea ana fera, to go to another country.

ana 7 . if, for, when, because, used of subjunctive.

ana 8. tangafulu ana, tenth in a series. S. ana 8

ani 1. v. tr. to eat. Mota gana; Florida gani.

anila, v. n. eating.

ani 2. instrumental, with; suu fafia ani taa, clothed with what? the pronoun a may be added, ka modea na toongi ua inao ania, to mend the old garment withal; liona kafi too ania, his heart shall be glad thereat. S. ani.

ani 3. prep. concerning, in; e langi ani nau, there is nothing in me; gera ote gera ani nau, they will have nothing of me. S. ani.

ani 4. poss. pl. 3, used of things only, for them; na doo da soi amu ani, the things which they asked you for. S. ani.

ani 5. v. suff.; ui, to throw, uiani v. tr., to throw a thing.

aniramo, v. tr., to do violence to. ramo.

ano 1. n., earth; si ano lofo, dust. S. 'ano. $C f$. gano.

anomi v. tr., to bury.

iano on the ground, down.

ano 2. v. i., to come to naught. S. 'ano 2.

angai v. tr., to lift, to carry. S. anga'i.

angi v. i., to cry.

angisi v. tr., to cry over. Mota tang.

angia, angila v. n., a cry, crying.

angita adv. with loc. $i$, $i$ angita, when? bye and bye. Mota angaisa. anu, anuanu v. i., to be shaken, to be loose. S. änu.

ao v. i., ao maa ilengi, to lift the eyes, to look up. S. aonga'i.

aqaa v. i., to be well, whole, convalescent. S. awaa.

aqala 1 . n. a ten, a tally; aqale mwai, ten baskets.

aqala (na) 2. n., its noise, the sound of it. S. awa 2 .

aqaoro v. i., to stoop. S. aqa oro.

arabuu v. i., to reach, arrive at. S. arapuu.

arai 1. n., husband; arai faalu, bridegroom; arai na luma, master of the house.

arai 2. n., a chief; inite arai, the elders.

arenga- (gu) n., part, duty. S. arenga.

ariabasi v. i., to strive, endeavor, attempt. S. lapasi.

ariri v. i., to be shaken. S. äriri.

aro v. i., to soar. S. aro.

asi 1. $n$., the sea, salt water, salt; $i$ toulana asi, on the surface of the sea; asi namo, a lake; busu asi, a whale. S. 'äsi.

asi 2. man's brother, woman's sister; used only with art. mwai; mwai asi, brethren. Cf. sasi. S. 'äsi. 
asi 3. v. tr., to cast away, to fall down; daro langi si asidaro laona kilu, shall they not both fall into the ditch?

asia 1 . adj., scattered;2. adv., much, excessive, very; tou asia na, very lowly; elangi asia, far from it, by no means. S. 'asi 'a. asua n. daylight, daytime; fe asua, a day. S. atowa. asufe n., a rat. S. 'asuhe.

ati interrog. pron. sing. who, pl. gerati; ati gera, who among them? ati susulia, who knows? (I can't say); doo ati, whose thing, who owns it? ati satana, what (who) is his name? S. atei.

ato 1 . v. i., to be in motion; ato buri, with poss., to turn the back on; ato folo, to cross over; lua e ato fafigera, the flood came upon them; ato ae, to move quickly, to hurry. S. ato 1.

ato 2. v. i., to be difficult.

au n., the bamboo, flute; musical instrument. S. äu 3 . auau; ngidu auau, to hate.

B

ba adv., gives force, explains, makes the diction less abrupt; ati ba, who then? $a$ doo $b a$, why so-and-so; go may be added, $a$ doo bago, the man there.

babala n., a tempest; babalai tolo, a hurricane.

babali (gu) n., cheek. Cf. bali. S. papali.

babara (gu) n., side (of persons only), loins. S. parapara.

babaranga n., a draught, shoal, of fish; babarangai ia, a shoal of fish. babataini v. tr., to throw down, break by throwing down, overthrow.

S. papa.

bae, babae v. tr., to speak, to say; bae fua, to rebuke.

baea, v. n., word; si baea, a word; a si baea, The Word.

baela (gu) v. n., word, the act of speaking; si baela nana, that word.

baita big, loud, to grow big; manata baita ana, to love a person; Mala baita, Big Malaita. It is worth notice that the last three letters of baita, viz, ita, are those which the Spaniards, the original discoverers of Malaita, added to the name Mala, by which Malaita is known to the natives of those parts. The part of the island which the Spaniards saw and named is called by its inhabitants Mala baita, and it is conceivable that the $b a$ of baita may have been lost in transcription. S. paine, Alite baila. The root is probably bai, and $t a$ a verbal suffix.

balafe v. tr., to thank, to praise. S. paalahe.

balafela v. n., praise, thanksgiving.

balala, bala v. i., used with fafi; balala fafi, to despise.

bali n., part, side, of position; ita bali logo, from over there; $i$ bali Jordan $i$ bali logo, from the other side of the Jordan; te bali babali, one cheek; te bali maa, one eye; cf. babali. S. papali, cheek.

bara n., a fence, gate, wall, courtyard; gule bara, family (tribe). S. para. 
baraa n., a feast.

baru n., a large sea-going canoe, ship (late use).

bata n., shell money. S. haa.

bebe n., moth, butterfly. S. pepe.

bele v. i., by mischance, by mistake, in error, of no avail.

belengaini v. tr., to do a thing by mischance, in error.

beli, belibeli v. tr., to steal, to rob, to steal from a person.

S. pele.

belila v. n., theft. S. peli.

beu n., a chamber in a house; kade beu, inner chamber.

bibii n., mud. S. qiqi.

bibisu n., shiny starling, callornis metallica. S. pipisu.

bibiu, mwela bibiu, a baby, an infant. ?Mota piopio.

bilage v. tr., to shut; bilage maa, to shut the door.

bili; fabili, to make dirty.

bilia adj., dirty, unclean.

bilili v. tr., to press upon, weigh down. S. pilingi.

bilingi v. tr., to press down.

binaae v. i., to shine, of sun.

binisi v. tr., to bind.

bito 1. v. i., to sprout, to shoot, to begin to grow; 2. n. a sprout; bitona e bito, it sprouted. S. qito.

bobola to be fitting, meet.

bobongi with loc. $i$, $i$ bobongi, tomorrow. Mota qong.

boe v. i., to be whole, big.

boeboela adj., whole, sound, fat, well.

bokosi v. tr., to hinder.

bola n., a pigeon, carpophaga rufigula. Florida bola.

bole; teo bole, to dream; teo bolea, teo bolela, a dream. S. qole, Mota qore.

bona v. i., to cease speaking, to be silent.

bono v. i., to close a hole; toongi bono maa, sackcloth. S. pono. bongara, bongangara, v. i., to succor, nourish; bongara fonosi, to oppose.

bongi; 1 . too bongi, to be sad of face.

bongi; 2 . dau bongi, to take hold of.

boro 1. (na, ni), borona aena, heel.

boro 2. adv., perhaps, probably, possibly.

boro 3. v. i., boro tafa, to emerge, come out from. S. pola.

boso n., a pig. Bugotu, botho, Florida, bolo, New Guinea, boro.

bota used with poss., blessed, to receive a thing gratis, to be well provided with; bota ana, haply.

fabota v. tr., to be of assistance to.

bouruuru v. i., to fall down, to kneel down.

bouruurula $v$. n. S. pouruuru.

bubu v. i., to look; bubu tete adalu, to look earnestly at them.

bubungi v. tr., to look at.

bubulu n., a star; fe bubulu, a star; a bottle (late use).

bubulua adj., black. S. pulupulu'e. 
bubungi; bubungi luma, a village. S. pungu.

bukonu v. i., to be grieved; lio bukonu, to be sad of heart. bulo, bulobulo v. i. to turn; afe bulobulo, a tide rip. S. pulo. bulu n., gall. S. pulu.

bungu 1. a shell trumpet; ufi bungu, to blow the trumpet. bungu 2. v. i., to be deaf; alinga bungu, deaf. S. pungu. buri (gu) n., back, stern, behind, after, of persons. buri mwane, second son.

burina after that; $i$ burimu, in your absence. S. puri. buro; lio buro, manata buro, to forget. S. pu'o. burosi v. tr., burosi lio, to keep in doubt. S. mahuro. buroburo v. i., to bubble, to spring up, of water. S. hure'i. buru v. i., to be narrow; tala e buru, narrow is the way. buruburu v. i., to be frequent; adv. frequently. S. puru. busu v. i., to squirt, to eject spray; busu asi, a whale. S. pusu.

\section{$\mathrm{D}$}

There is no sound of $n$ in the $d$. The pronunciation of $d$ in Lau is much the same as that of $d$ in English.

da 1. pers. pron. pl. 3. they; used by itself as subject, or follows igera; igera da ada, they saw.

da 2. pers. pron. sing. 3 . suffixed to verb and to prepositions as an anticipatory object, them.

dada v. i.; dada fafi, to leave undone; to pass over.

dadaola, daodaola adj., tired; noni daodaola, weary.

dafi n., the golden lip pearl shell, a pearl; fufue dafi, pearls. S. dähi. dalafa v. tr., to strike against, to hit.

dali v. i., to tread upon; uri dali, to tread under foot. S. pulisi.

dalu 1. pers. pron. trial 3. they; used by itself as subj., or follows idalu.

dalu 2. pers. pron., trial 3. suffixed to verbs, and prepositions, as object, and to prepositions as an anticipatory object, and used of persons only, them.

daluma (gu) n., middle, in the midst of ; used with loc. $i$.

S. dänume.

dangi n., day, e dangi na, it is daylight; dangiliu, brightness, glory; maaedangi, a day; suli dangifiri, daily. S. dängi.

dadangi v. i., to be daylight.

dao v. i., to arrive; rodo $f$ dao, till nightfall; dao ana, until. S. dao. dara (gu) n., forehead. S. dara.

daraa n., a young man; maa ni daraa, a young man.

dari n., a valley, a creek. S. dä'iderie.

daro 1. pers. pron. dual 3. they two; used by itself as subj. or follows idaro.

daro 2. pers. pron. dual 3. suffixed to verbs and prepositions as object, or to prep. as an anticipatory object, the two of them. darongai v. tr., to scatter, cause to disperse. S. daro' $i$. dasa n., fog, mist. 
dau, dadau v. i., to hold, catch, take, touch; used with poss.; dau agu, touch me; dau toogu, meet me. S. däu. 1.

daula v. n., holding, touching.

dedengi v. tr., to pour out. S. dede'i.

dee, deedee v. tr., to catch fish; mwane deedee, a fisherman.

deela v. n., dee ana deela, to fish.

didi v. tr., to carve, to grave. S. didi 2.

diena adj., good, proper, accurate, beloved; lio diena fafi, to delight in, to love.

dienala v. n. U. diena.

dila v. i., to jump down. S. dile.

dingalu; sui dingalu, completely finished.

dodoria adj., clear, open, of path.

dole v. i., to delay, to be a long time.

dolofi v. tr., to rub in the hands.

donga v. i., to spread, to circulate.

dongaa adj., consecutive. S. donga 2.

doo n., thing; the noun ending may be added; with the personal article, $a$ doo, the person, so-and-so, such an one; ni doo ne, the woman, woman (Voc.); doo mamana, truly; ade doo, to worship; dooa, doola v. n., saitama dooa, wisdom; ade doola, worship; cf. S. ola.

dori v. tr., to wish for, desire, love.

dudu v. i., to move position; dudu mai, come hither; $d u d u$ oli, to retire. U. $d u d u$.

dumuli v. tr., to lay hold of.

duqe v. tr., to split, burst, wound; too duqe, to cause to burst open; ofu duqe, to burst.

duu v. tr., to visit upon, punish, repay. qaiduu, to revenge.

duulana, with loc. $i$, $i$ duulana, because of.

duula v. n., recompense.

$\mathbf{E}$

e. 1. used to make a construct form, added to the first of two nouns, fuli abae ai, man's handiwork; toloe fera, a hill; when the first noun ends in $a, a e$ is contracted into $e$, aqale mwae, ten bags; fufue $a i$, seed; when the first noun ends in $o$, the oe is contracted into $e ;$ abolo, piece, abole ai, log. Cf. Mota, construct form of nouns, where the ending of the first noun may be altered to $e$.

e. 2. pers. pron. sing. 3. he, she, it, used to precede nia when the meaning is, there is, it is: na liqa gera enia ada, they have their holes; ma te ai enia $i$ luma, there is only one person in the house; generally used of the neuter; e langi, no, not; e langi ana, it is lost; e langi o si sulu isulia, you must not follow him; e sui na, it is finished; e uta, how? S. $e$.

e. 3. v. p., used with numerals and with fita; e rua. two; e fita, how many? S.e. 
eela adj., lazy; noni eela, lazy.

eelenga (na) $n$., the end of, its end.

eeo v. i., to be crooked.

ele v. i., to desire, used with uri; ele uria, desirous of it.

elela v. n., rejoicing.

elea adj., joyfully.

eli, elieli v. tr., to dig.

elila v. n., digging. S. eli.

enia pers. pro. sing. 3 . he, she, it; enia naane, that is so; gele mwela

enia ada, the small child (he) was with them. Cf. e. 2 .

eqetaini v. tr., to remit, forego.

ere 1. n., fire; alu ere ana, to set fire to; si ere, a firestick.

ere 2. v. tr., to plait.

ereere v. tr., used as prep., round about.

ereila adj., round in shape. S. ere.

erisi v. tr., to despatch, send. qaierisi.

eta numeral, one; eta inao fua, to be in front of, to lead.

etana, ordinal, first, the first time. S. eta.

fa. 1. causative prefix, applied to verbs and less frequently to nouns, e. g., famwaela. S. ha'a.

fa. 2. termination of verbal nouns: mae, to die, maemaefa, sickness; otofa-, concerning, offa-, approaching, are always followed by the suffixed pronoun. S. ha.

faabu v. tr., to forbid. S. 'abu.

faabua v. n., an oath.

faabusu v. tr., to fill, satiate with food.

faada v. tr., to cause to see, to awaken. ada.

faado v. tr., to apportion. S. ado.

faalamaini $v$. tr., to entrust, to permit. alamai.

faalu, faolu, adj., new, fresh, recent; arai faolu, bridegroom.

S. haalu.

fabaita v. tr., to make big, to magnify oneself. baita.

fabili v. tr., to make dirty, to defile. bili.

fabona v. tr., to appease, to cause to be quiet. bona.

fabota v. tr., to be of assistance to. bota.

fabulosi v. tr., to cause to turn, to turn over. bulo.

fadole v. tr., to be a debtor to.

fafanafi v. tr., to covet. fana.

fafanga v. tr., to feed. fanga.

fafaraasia adj., tasteless.

fafi 1. v. tr., to help; dau fafi, to help, to surround; 2. prep. concerning, causation; fafia, because of. S. haahi.

fafo $(\mathrm{gu}) \mathrm{n}$., above, over, used with locative $i$., $i$ fafona, in addition, on top of it.

fafola v. n., alu fafola, addition. S. haho. 
fafolali v. tr., to illuminate. fola.

fafolifoli v. tr., to signify, to explain. folifoli.

fafou v. tr., to proclaim. fou.

fafunu v. tr., to destroy, to cause to end. funu.

fafungu v. tr., to fill. fungu.

fafurongo $\mathrm{n}$., a disciple. rongo.

fafuta v. tr., to generate, to beget; said of both parents.

fafutala v. n., a generation. futa.

fafuu used with possessive ana; fafuuana, real. fuu.

faga (gu) n., mouth. Niue fangai, to feed; Mota wanga, to gape;

S. awanganga, to gape.

fagaro v. tr., to deceive, to cause to stray. garo.

fagwau v. tr., to make desolate. gwau.

fagwoufi v. tr., to give drink to. gwou.

fagwourufi v. tr., to cause to sit down. gwouru.

fai 1. v. tr., used as prep., with, to help; fai oe, with thee.

faini v. tr., to help, to companion with; fainia, moreover.

fai 2 . adv., where? used with locative $i$, or with prefix $n i$; ifai, nifai. $\mathrm{U}$. hei.

fai 3. pref. to verb; buri, behind, faiburi, to leave behind; faigwa, to spill.

fai 4. numeral, four, faina, ordinal, fourth, the fourth time.

faiburi used with poss., to leave behind. $f a 1$.

faigwa v. tr., to spill, to shed.

fakukule v. tr., to cause to hang down.

fakulufi v. tr., to let sink, to lower. kulu.

falaete adv., only. S. häli'ite.

falangi 1. n., a house on piles. S. ha'alangi. langi 2 .

falangi 2. v. tr., to bring to nothing, to destroy. langi 1.

falauni v. tr., to decorate, to adorn. launi.

fale v. tr., to give; fale aba fafi, to lay hands on.

falela v. n., a gift.

fali, fafali v. i., to walk, tread; fali folo, to turn aside. S. palili.

falisi n., garden, crop, season, year. S. hä'lisi.

falooi v. tr., to torment, treat shamefully. loo.

famae 1. v. tr., to kill. mae.

famaesi v. tr.

famae 2. v. tr., to quench. mae.

famafo v. tr., to heal a sore. mafo.

famamana v. tr., to establish, to make true. mamana.

famanatai v. tr., to instruct, teach. manatai.

famou used with poss., to warn, terrify, hold in honor. mou.

famwaela used with poss., to laugh at. mwaela.

fanau v. tr., to teach, educate. S. ha'ananau.

fana v. i., to shoot. S. hana.

fanasi v. tr., to shoot, to covet.

fanina v. tr., to be wont, to accustom.

fanonifi v. tr., to torment. noni.

fanualama n., peace. S. hanualama. 
fanga v. tr., to eat, to bite (of fish); toli fanga, to fast, abstain from. fangaa $v$. n., a feast.

fangala v. n., food; ade fangala, to make a feast.

fangado v. tr., to make strong; fangado rage, to comfort. ngado.

fangasi v. tr., to harden.

fao, faofao v. tr., to weave, to plait. S. hao.

faolo v. tr., to make straight.

faolofi v. tr., to make straight, to justify (late use).

faolu adj., new, recent, fresh. U. ha'olu.

faorai v. i., to plot, take counsel, consult, talk together.

faoro v. tr., to multiply.

faoroa adj., of ten. oro.

faqaqaoa v. tr., to make clean. qaqaoa.

faqaqari v. tr., faqaqari lio, to comfort.

fara ( $g u) ~ n .$, beneath; with locative $i, i$ farana, on the earth.

fararao v. tr., to cause to stick. rarao.

farifari n., a scorpion. S. häriheri.

farodo v. tr., to darken; farodo maa, to blind the eyes. rodo.

fasaa ; fasaa fua, to curse; bae fasaa ana, to curse anyone.

fasi (nau) 1. prep., from, motion from.

fasi 2. adv., a while; makes the diction less abrupt; o lea fasi, please go; alua fasi, put it aside, i. e., wait a while, presently.

fasi 3. v. tr., to sow, to plant. S. häsi.

fasia dehortative, don't! fasia oko lea go, do not go; o fasia oko luia lau, do not forbid it any more. fasi 2.

fasifa v. tr., to sell, to hire.

fasifala v. n., price, hire. sifa.

fasui v. tr., to finish; fasui lio, to satisfy the mind. sui.

fasusu v. tr., to give suck to. susu.

fataali v. tr., to do harm to, to spoil. taa.

fatai partic., out, clear.

fataia v. n., a manifestation. S. ha'atai.

fatake, fatakesi v. v. tr., to cause to stand, to set up; fatake qaimani, to be a peacemaker. take.

fataofai v. tr., to cause to stumble, to offend (late use). taofai.

fatau v. tr., to cause to be far off. S. ha'atau.

fatemaea n., a wonder, a miracle; si fatemaea.

fateofi v. tr., to cause to lie down, to put to sleep. teo.

fateqa $\mathrm{v}$. tr., to lengthen. teqa.

fatona v. tr., to cause amazement to.

fatou v. tr., to humble. tou.

fe 1. article, a; used of things spherical in shape; fe bread, a loaf; fe bubulu, a star; fe gale bola, a young pigeon; fe kakarai kua, a hen's egg; fe rade, a reed; na or ta, or te, may precede; fe uo, a hill; tefuana ta fe uo, every hill; na fe uo, a hill; te fe mwela matala, an only son; used of one of a series; fe asua, a day; fe rodo, a night; used as a multiplicative; ro fe angia, two cryings; fita fe ade doo taa fuagu, how many sinnings against me? $C f$. qe. 
fe 2. (a) marks repetition or restoration or continuance; is accompanied by adv. lau, again; na abana e fe boeboela lau, his hand was restored whole; daro fe lea lau go, they two went on; (b) used as an illative, in that case, following upon. S. hei. fera n., land, village, habitation; fera fu, heritage; fera gwou, a deserted village. S. hera.

Ferasubua artificial islet north of Fuaga.

fi illative, in that case, then, following upon, just now, for the first time; follows the verbal particles $k a, k o$, but a particle need not be used; gami mi fi saitamana na tala, and how shall we know the way?

fi 2. trans. suffix to verb; tau, to wash; taufia abana.

fidali v. tr., to clap the hands, to strike with the hands. S. hideli. fii v. i., to be in pain, to hurt. S. hii.

fila v. n., pain. nonifii.

fili; taifili, alone. S. hili.

filo; ada filo, to choose, to perceive; too filo, to perceive.

finau n., a hook. S. hinou.

fiolo v. i., to be hungry.

fioloa v. n., hunger. S. hi'olo.

firi adv., always, lasting; too firi, everlasting; suli dangifiri, daily.

firu v. i., to fight with weapons.

firula v. n., a fight, war; na firula.

fisu, fifisu v. tr., to pluck.

fita interrog. adv., used with $e 3$; e fita, how many? sasigu ka fita fe ade doo taa fuagu, how often shall my brother wrong me? S. nite.

fitali v. tr., to split; too fitali, split in sunder. S. hideli.

foaa v. tr., to pray.

foaataini v. tr., to pray for.

foaala v. n., prayer.

foda v. tr., to shut, to close.

foela v. n., division, schism.

foga $v$. i., to be open, to rend. S. ho'a.

fola v. i., to shine, to be clear; lioda kasi fola, their minds shall be clear; bae fola, to speak plain.

folala v. $n$., light, clear, shining.

folaa n., a calm. S. holaa.

folifoli v. tr., to measure, to signify, to exemplify.

folifolia v. n., a measure.

folo, fofolo 1. v. tr., to guard; folo fonosi, to protect.

folola v. n., a guarding.

foloa v. n., guardian.

folo 2. v. i., to cross over; fali folo, to turn aside towards; ato folo, to cross the sea. rarafolo.

fono v. i., to be full; aqala fono, a full ten. Mota wono.

fonosi (nau) verb used as preposition, against, to meet, to protect. S. honosi. 
fonu n., a turtle. S. honu.

foosi v. tr., to officiate, conduct service.

fote 1. v. tr., to paddle; 2. n., a paddle; si fote. S. hote.

fotoi v. tr., to hit, to crucify.

fou 1. rock, stone; si fou, a rock. S. häu.

fou 2 . v. i., to proclaim.

foulai v. tr., to proclaim. S. hou.

founia, faunia n., a sacrifice.

fousi v. tr., to turn, to reverse.

fu 1. v. i., to be grieved. S. $h u$.

fu 2. adv., real, permanent, for good; ngali fu ana, to take it permanently. S. $h u$.

fua- (gu) 1. prep. to, for, dative, motion towards; falea fuana, give it to him; mae fuana, die to his disadvantage; soe ledia fuana, question him about it; bae fua, forbid anyone; in order to, fua qaimani, in order to help; ngado fua, trust (a person).

fuana used as subjunctive or optative.

fua 2 . $n$. ashes.

Fuaga artificial islet inside reef at Ataa Cove.

fuagalo v. i., to be in good time, early afoot in the morning.

fuasa, a crocodile. S. huasa.

fualangaa n., sin.

fufua (na) n., fruit; fufue ai, seed; fufuana, its seed. S. hue.

fufusi v. tr., to scatter, to sow.

fulaa $\mathrm{n}$., a spring of water. S. hulaa.

fuli n., place; fuli abae ai, men's handiwork; fuli fera, village; $i$ fulini, in their place (neuter). S. huli.

fulo 1. v. tr., to wash, to sponge; n., a sponge. S. hulo.

fulo 2. v. tr., to prepare; fuloa na tala, to make ready a way.

funu v. i., to come to naught, be destroyed; ani funu, to eat up, devour; doo funu gi, things of naught, vanities.

fungo (gu) n., relations at law; fungona Peter geni, Peter's motherin-law. S. hungao.

fungu 1. v. i. to bear fruit. S. hungu.

fungu 2. v. i., to be full. S. honu.

funguli v. tr., to oppress, cause sorrow to.

furai $\mathrm{n}$., a net; furai ana deela, a fishing net.

futa v. i., to be born.

futala v. n., generation. S. hute.

fuura v. i., to be dropsical. S. pule.

G

gagaro (gu) n., flank, side, of persons. S. karokaro.

galai v. tr., to strike, beat.

gale adj., precedes noun, small, little, of young persons or children; ro fe gale bola, two young pigeons. S. kele.

gali (nau) verb used as prep., round, around; lea galia, go round it. S. kali. 
gamelu 1. personal pronoun trial, 1. excl. we; used by itself as subj. or follows igamelu.

gamelu 2. as gamelu 1. but suff. as obj. to v. and prep.

gamere 1. pers. pron. dual 1. we two; used by itself as subj. or follows igamere.

gamere 2. as gamere 1. but suff. as obj. to v. and prep.

gami 1. pers. pron. pl. 1. excl; we; used by itself as subj. or follows igami.

gami 2. as gami 1. but suff. as obj. to v. and prep.

gamolu 1. pers. pron. trial 2. you; used by itself as subj. or follows igamolu.

gamolu 2. as gamolu 1. but suff. as obj. to v. and prep.

gamoro 1. pers. pron. dual 2. you two; used by itself as subj. or follows igamoro.

gamoro 2. as gamoro 1. but suff. as obj. to v. and prep.

gamu 1. pers. pron. pl. 2. you; used by itself as subj. or follows igamu.

gamu 2. as gamu 1. but suff. as obj. to v. and prep.

garangi (nau) verb used as prep., near; adv., almost. . S. kara'ini.

garo v. i., to be astray, loose, to be lost, to wander, to be wrong; manata garo, to think astray, to err.

garola v. n., transgression. S. takalo.

gau 1. v. tr., to extract, to pluck.

gau 2. v. tr., to bind.

gefu, gefusi v. v. tr., to tear down, to roll away, to remove.

gege; ada gege, to look behind.

Adagege, name of artificial islet next to Ferasubua. S. keke 3. gele 1. adv., a little, somewhat. 2. adj., little; gele qe ia gi, small fishes. S. kele.

gelogelo v. i., to be shaken.

gelogeloa adj., shaken. S. kulekule.

geni n., a woman; ni geni ne (Voc), woman; tole genila, marriage. S. keni. Alite mangeli.

gera 1. pers. pron. pl. 3. they; used by itself as subj. or follows igera; used to mark plurality; gera priest; gera na Judea. S. kire.

gera 2. as gera 1 . but suff. as obj. to v. and prep.

gi article, denotes plurality, follows the noun; na mwane gi, the men; na mwane oro gi, many men; used with the forms of the pers. pron. pl. but not with those in lu; gi may be separated from the noun; na doo nia gi, his things. S. ' $i 8$.

gia 1. pers. pron. pl. 1. incl. we; used by itself as subj. or follows igia. S. ki'e.

gia 2. as gia 1. but suff. as obj. to v. and prep.

gidigidi v. tr., to knock with the knuckles.

ginigini v. tr., to pinch. S. 'ini.

girigiri; girigiri lifo, to clench the teeth; girigiri lifoa v. $\mathbf{n}$. 
go 1. adv., of place, there, thither, away; added to lau; e bae lau go, he said also; logo, over there; sifo go, come down, descend. S. wäu.

go 2. a demonstrative; inau go agu, I for my part; tefe doo go ana, only one thing; ne may be added; inia gone, that is it. S. hou 2.

golu 1. pers. pron. trial 1. incl. we; used by itself as subj. or follows igolu. S. kolu.

golu 2. as golu 1, but is suff. to v. and prep. as obj.

goni, gonitai v. v. tr., to receive, to keep, to observe and do. S. koni. goro 1. pers. pro. dual 1. incl. we two; used by itself as subj. or follows igoro. S. kure.

goro 2. as goro 1 . but is suff. to v. and prep. as obj.

gougou (na) n., husk, shell.

gu 1. pers. pron. sing. 1. I, used by itself as sub. or follows inau. Florida, $k u$.

gu 2. as gu 1. but is suff. to v. and prep. as obj.

gula n., place, part; gula $i$ maa, outside; gule bara, family.

gulu v. i., to be heavy, to be enceinte.

gulufi v. tr., to be too heavy for.

gulua adj., heavy.

gumu v. tr., to strike, to punch. S. kumu.

gutafi v. tr., to persecute. S. kotahi.

gwa; faigwa, to shed, to spill.

gwaa v. i., to be open, of ears. S. wa'a.

gwagwaria adj., patient, gentle.

gwai 1. v. tr., to anoint; 2 . n., ointment.

gwaila v. n., anointing; gwai ni gwaila.

gwalifoa v. tr., to cause to sink.

gwalu 1. v. tr., to promise.

gwalua v. n., a promise.

gwalula v. n.; a promising.

gwalu 2. v. i., to moor a vessel.

gwaofa n., house, ridge. S. qaoha.

gwaofai v. tr., to hide, to cover over.

gwari adj., cold; kafo gwari, cold water.

gwarimabe v.i., to be gentle, quiet, sober. gwagwaria.

gwau, gwou (gu) n., head. S. q'äu.

gwaunga, gwounga n., a generation; gwaunge, mwane, a generation of men. S. qäunge.

gwauru, gwouru v. i., to kneel, to bend. S. pouruuru.

gwautoli, gwoutoli v. i., to bow, to bend. S. qü'utoli.

gwegwe v. tr., to buffet; salo e gwegwe gera, the wind was contrary to them.

gwelu; tatagwelu, headlong. S. tataqelu.

gwini, gwinigwini v. i., to be moist, wet. S. qini.

gwou, gwougwou, gwouf, 1. v. v. tr. to drink.

gwoula v. n., a drinking. 
gwou, gwau 2. v. i., to be deserted, overgrown, of gardens; to be apart; to be empty, finished, of a vessel; fera gwou, a deserted village.

gwoutai v. tr., to be apart, alone; e gwoutai daro, they two were alone. Mota wou.

gwoubusua a hill. gwou, head.

gwouru, gwauru v. i., to kneel, sit.

gwourula session. S. pouruuru.

gwoutai, gwoutaini v. v. tr., to bow the head.

gwou ulunga n., a pillow. S. qä'u ulunge.

\section{I}

1. locative; always used before names of places; always with adverbs of time and direction; ifai, where? $i$ daluma, in the midst; $i$ Ramarama, at Port Adam; $i$ kade manga na, at that time; $i$ angita, when? $i$ se, $i$ sena, here. Forms the compound prepositions ifafo, $i$ fara, $i$ lao. S. $i$.

i2. genitive; geni $i$ Saa, a Sa'a woman; ro kesi kurui bata, two pieces of money; used to express purpose, lea $i$ fasifa, go to purchase. S. $i$.

i 3. prefix to personal and demonstrative pronouns; inau, igoro, igia. S. $i$.

i 4. instrumental prefix forming noun from verb; kamu to eat areca nut, ikamu, a lime spatula.

i 5. verbal suffix; manata, to think, manatai, to pity. S. ' $i$.

ian a fish, a fish tooth (porpoise); qe ia, a fish. S. $i$ 'e.

iano adv., on the ground, down; mai iano, on the earth.

iangita adv., when? at what time?

ibobongi adv., tomorrow. Mota qong.

ida v. i., to be ashamed, to reverence; ida fasi, to reverence.

idala v. n., respect, shame.

idalu pers. pron. pl. 3. they; used by itself as subj. or follows dalu, more restricted in application than igera.

idaro pers. pron. dual 3. they two; used by itself as subj. or follows daro.

idu 1. v. i., to count.

idumi v. tr. S. $i d u$.

idu 2. v. i., to move position; lea $i d u$, to pass by; lea idu mai, to enter.

idula- (gu) $n$., on behalf of.

ie (gu) n., stomach, womb. S. 'ie.

ifafo (gu) prep. above; maaedangi $i$ fafo, two days ago.

ifai adv., where.

ifara (na) n., underneath.

ifi $v$. i., to open.

ifingi v. tr.

ifitai $n$, a mat, a bed.

ifitaini v. tr., to spread as a cloth. 
ifu (gu) n., hair. S. ihu.

ifu v. i., to be uprooted.

ifula v. n., a fall, an uprooting.

igamelu 1. pers. pron. trial excl. 1. we; used as subj.; more restricted in application than igami.

igamere pers. pron. dual 1. excl. we two; used as subj.

igamolu pers. pron. trial 2. you; used as subj.; more restricted in application than igamu.

igamoro pers. pron. dual 2. you two; used as subj.

igamu pers. pron. pl. 2. you; used as subj.

igera pers. pron. pl. 3. they; used as subj.; also as plural article; igera fiolo, the hungry. S. ikire.

igia pers. pron. pl. 1. incl. we; used as subj. S. iki'e.

igolu pers. pron. trial. 1. incl. we; used as subj.; more restricted in application than igia. S. ikolu.

igoro pers. pron. dual 1. we two; used as subj. S. ikure.

iida (na) n., pinnacle of house.

iidimani only, just, to be about to; iidimani si doo, the uttermost farthing; tesi gula iidimani, the merest piece.

ikamu n., a lime spatula.

ilangi adv., up, above, in the sky.

ilefou n., a precipice; fou.

ili v. i., to choose; ili doo, to choose. S. ilisi.

ilisi v. tr.

ilao (gu) n., used as prep.; within; ilaona, inside. S. ila'o.

ileli v. tr., to judge.

ilelia adj., bruised.

ilifaini v. tr., to give commands to, to signify.

ilitoo v. tr., to tempt; takes $g u, m u, n a$, as pronominal suffixes; a ilitooa v. n., the tempter.

imaa adv., outside, in the courtyard.

i moumouli (gu) on, in, the left hand (late use).

inakesi v. tr., to examine, take account of, beseech, importune; inakesi ingola, to beseech.

inala v. i., to discern by casting lots. S. ilala.

inali 1. v. tr., to plait; 2 a rope. S. $i$ 'eli.

inao $(\mathrm{gu}) \mathrm{n}$., before, in front of, of old time. S. ina'o.

ini v. tr., to pinch, ini $i$ luana, to throttle. S. 'ini.

inia pers. pron. sing. 3 . he, she, it; used as subj. and followed by nia. S. inge'ie.

inite; inite; arai, the elders.

initoo to be glorious; soe initoo, to glorify; too initoo, the rulers; initoo, initoola, majesty.

inumae v. i., to be orphaned, to be poor.

inumaea v. n., an orphan. S. inemae.

inunufa- $(\mathrm{gu}) \mathrm{n}$., because of. S. inunuha. 
ingo $\nabla . i$. to beseech.

ingosi v. tr., to beseech.

ingotaini v. tr., to provoke.

ingola v. n., inakesi ingola, to beseech.

ioe pers. pron. sing. 2. thou, used as subj. and followed by $o$. S. $i$ 'oe. iqa v. 1 . to be spoilt, shed, of fluid.

irogi adv., yesterday.

irori v. tr., to mix, mingle, stir up.

isara adv., shore, to the shore.

ise, isegi, ise na adv., here.

isi; isilana, the end; isiburi, to be last, finally; isingana ne, from henceforth; sae isingana, leave off speaking.

isuli prep. motion after, motion over; isulia rodo mana asua, by day and night; lea isulia, go after him. S. isuli.

ita adv., motion from; ita ana mai, up to here; ita mai ifai, whence; ita na mai inao, from of old.

itafu- (gu) n., on behalf of.

iu, iuka affirmative, yes.

\section{$\mathbf{K}$}

ka verbal particle, used of present or of future time, or of consequent action; nia ka bae uri, he speaks thus; gamelu ka ania si taa, what shall we eat? sui ta nia kafi bae uri, thereupon he says; lelea ka rodo, go till nightfall; may be used in negative sentences with the addition of si, not; kasi bobola, it is not fitting. U. 'a.

kada n., a period; kada na, kada ni, at the time when; $i$ kada uta, when? kade manga, while; kade beu, inner chamber.

kafo water; si kafo, a bamboo water carrier.

kakalu a well of water. S. kilu.

kakamu (na) n., edge, border.

kakao basin, vessel, coconut shell cut to make a spoon. S. kaokao. kakara egg; fe kakarai kua, hen's egg.

kakasi v. tr., to carve.

kakau (gu) n., finger. S. käu.

kame (na) n., used with locative $i$, by the side of (of things).

kamu v. i., to eat areca nut. S. damu.

kani v. tr., to bind.

kanila v. n., a binding.

kanikulu v. tr., to hang up, suspend.

kao a bamboo water carrier. Cf. kafo.

kari v. tr., to tear, rend, break open, take to pieces.

kau, kakau, v. tr., to bind, tie.

kakari v. i., to be torn.

kauraa v. tr., to mend, patch.

ke article, followed by si 2 ; ro kesi kurui bata, two pieces of money; added to te, teke si gula, a part. 
kede, kekede v. tr., to cut, carve, write.

kedela $\mathrm{n}$., inscription, writing, letter.

kedekedea, kekedea, adj., gorgeous, bright-colored.

kekerofa (na) n., of, amongst; ada kekerofana, choose from among; mou kekerofana, fearful of.

keketo $\mathrm{v}$. tr., to judge.

keketola v. n., judgment.

keo v. i., to be blind; mwane keo, a blind man.

kete (gu) 1. n., head; $i$ ketena, on his head.

kete 2. v. tr., to cut; too kete, to cut in pieces.

ki v. i., to be troubled in mind; liona kafi ki, his mind was troubled.

kiki v. tr., to pour.

kila a stone axe. S. 'ile.

kilu a hole, grave, well; kilu ni kafo, a well of water. S. kilu.

kilugwou a tomb. S. kiliqeu.

kirio porpoise. Mota ririgo. S. 'iri'o.

ko 1. verbal particle, used only with o pers. pron. sing. 2. oko; denotes consequence of action, used of present or future time.

ko (gu) 2. n., ancestor; ko gia gi, our fathers. S. kookoo.

kobu v. i., to be fat.

kobukobula, adj. fat.

koburo N. W. wind. Florida komburo.

kokomu an islet. S. komukomu.

kone 1. n. a flood of waters; 2. v. i. to be in flood. S. kone.

kore; ruru kore, an avalanche. S. kore.

kua fowl; kakarai kua, fowl's egg.

kubou a staff.

kudo; qae kudona, guiltless.

kukui a dog. Mao. kuri.

kulu 1. v. tr., to bury at sea. S. kulu.

kulu 2. cf kanikulu.

kuru 1. a piece, section, kurui bata; a piece of money, ro kurui doo, two sections.

kuru 2. v. i., to be maimed.

kuru 3. v. i., to sink.

kuta v. i., to shake. S. kute.

la 1. termination of verbal nouns; attached to verbs; mae, to die, maela, death; bae, to speak, baela, speech; the meaning seems to be gerundival and to denote the act of doing a thing. $C f$. S. la 5 .

1a 2. termination of the verbal nouns, attached to certain nouns; te, mother, ro muai telana, mother and daughter; attached to verbs; tasa, ro fe tasala, twice as much.

la 3. adjectival ending; attached to verbs; taga, to be scattered, tagala, promiscuously; tagalo, to be lost, tagalola, lost; teo, teteola; attached to nouns, mwai, mwaila. 
labu v. tr., to assault. S. räpu.

labua $\mathrm{n}$., point, prick, splinter.

lada v. i., to fall down. S. lada.

lade deep water, secure anchorage. S. lade.

lado v. tr., to join, knit; lado ae, to follow.

ladola v. n., a member.

lafi, lalafi v. v. tr., to take up, pull up, draw out, Mota lav.

lafu 1. v. tr., to pull, to wrench, pluck.

lafu 2. to be worn out, old; lafue toongi, old clothes. S. lähu.

lafusi, lalafusi, v. tr., to be ignorant of.

lai transitive suffix to verb; tege, tegelai.

lala v. i., to stretch; lala fonosi, protect.

S. $l a^{\prime} i$.

lalaba v. i., to walk about. S. la'alapa.

S. lala'i.

lalabata, court yard.

lalago v. i., to cling. S. nanako.

lalano the ground immediately above the beach.

lalanga v. i., to be dry, without coconut milk (of yam puddings), unleavened; usu lalanga to wipe dry. S. langa.

lali (na) 1. n., root, lali ngado, to be firmly rooted.

lali 2 . v. tr., to drive.

lalao v. i., to run.

lalaoa v. n., a herald. Mota valago.

lalifu (na) n. corner.

laliqate v. i., to make an oration, to preach.

laliqatela v. n. S. wate.

lamua a dove; fe lamua; ta ro fe lamua, two doves.

langae, to throw; langae fou, to cast stones.

langi 1. negative, no, not; $e$ may be prefixed; used as negative particle; e langi nau gu lea, I did not go; si may be added, nia langi si saea, he does not know, e langi nau gu si lea, I am not going; e langi si langi lau, not again; langi lau no more; langi $a n a$, not existing, lost; langi ta, or, if not; ma langi, ma $e$ langi, or not, in questions; lalangi ana, nothing.

langi 2. sky, heaven; ilangi. S. längi.

lao (na) $\mathrm{n}$, in; lao rodo, at night; $i$ laogamu, amongst you, in you, laona maamu, in your eye. S. lalo.

laongi v. tr., to cross, step over; S. laongi.

Lau 1. name of the language spoken by the coast peoples of Big Malaita on the artificial Islets off northeast coast, spoken also at Port Adam on Little Malaita.

lau 2. adv. again, anew, also; go may be added, inau lau go. S. lou.

lau 3. v. tr., to wrest, abduct; lau doola, extortion; lau fafi, to deliver. S. läu.

lausi v. tr., bae lausi, to compel.

lea lelea, v. i., to go; lea fonosi, to afflict; lea isuli, to follow.

leafi v. tr., to cause to move.

lelea v. n., going.

leala v. n., a herald. S. lae. 
lebelebe v. i., to be weak, sick.

lebelebela $v$. n., trembling.

ledi 1. v. tr., to ask a question; soe ledi, to question a person.

ledila v. n., questioning.

ledi 2. v. tr., to abominate, to renounce; qailedi. S. leledi.

lelefe, a dish, bowl, of wood.

li 1. genitive; maalimaea, enemy; maalitafa, channel; a variant of $n i$.

li 2. transitive suffix to verbs. mae, maeli.

lifo $(\mathrm{gu}) \mathrm{n}$. tooth; girigiri lifoa, gnashing of teeth. S. niho.

liligali (nau), prep. all around. S. lilikeli.

lima 1. (gu) n. hand, arm. S. nime.

lima 2. numeral, five; e lima. S. lime.

limana ordinal, fifth, the fifth time.

lingisi v. tr., to reverse, turn upwards. S. lingi.

liqa, cave, hole. S. liwe.

liu, liliu v. i., to ply, come, pass by; liu idu, to pass by; liliu kali, to spread; liu inao fuagamu, go in front of you.

liufa v. n., an epidemic. S. liu.

lio 1. v. i., to look, seem.

lio (gu) n., appearance. S. lio.

lio 2. (gu) n., heart, mind; lio sarofaia, harmless; lio bukonua, sorrow; ro si lio double mind; lio too, to be wise, lio tooa, lio toola, wisdom; alu te si lio, to be brave.

lita (gu) n., waist, loins.

lo adv., there, used with go, and gi; ita mai logo, thence; logo north west; na ogule boso logi, the herd of swine over there.

lobo v. i., a lake, pond. S. lopo.

lofo 1 v. i., to jump, to fly; lofo laongi, to jump over; ano lofo, dust.

lofoi v. tr., to assault. S. loho.

lofo 2. (na) n, in the neighborhood of, over against, opposite to; $i$ lofona fera, opposite the village.

logosi v. tr., to incline, bend. S. lolosi.

lola v. i., to drown.

lologu v. i., to be palsied, crippled. S. loku.

lolosi v. tr., to bend. S. lolosi.

lolou v. i., to make a noise, reverberate. S. lolou.

loo v. i., to be fierce, wild, suspicious.

falooi, to persecute, cause to be wild. S. loo.

looua grass.

loulou 1. v. i., to be quick; 2. adv., quickly, quick. S. läuleu.

loulou 3. adj., whole, entire, in one piece. S. läku.

lu contraction for olu three, used to form trial number of pronoun; dalu, golu, etc. S. lu.

luga v. i., to loose.

lugatai, lugataini v. v. tr.

lugala v. n., loosing. S. luhe.

lui v. tr., to forbid, reserve; alu lui to set a taboo mark on. S. luu'i.

lukumi v. tr., to restrain. 
lulua 1. a stranger, guest.

lulua 2. a basket of plaited coconut leaf. S. luelue.

luu v. tr., to move, to depart. S. luu.

$\mathbf{m}$ adjectival prefix; moi broken.

ma 1. conjunction; ma ana, though; ma ka langi, or not, in questions; $m a$ ta, but.

ma 2. adjectival prefix of condition; madiu; matala. S. ma.

maa 1. (gu) n., eye, face, aperture, gate; $i$ maa, at the door, in the courtyard; gula $i$ maa, outside; maana bara, gate; maa too (gu) to visit; toongi bono maa, sackcloth: 2 . art. one, a; maa ni dara gi, young men; fai maae oru qailiu, the four winds; maae dangi, a day, maae dangi $i$ fafo, two days hence; maae rodo, darkness; maae fera, a village. S. maa.

maa 3. voc., father; maa nau, father. S. ma'a.

maabala to no effect; rao maabala, to work unprofitably. S. maatala. maabe v. i., to be willing; mu maabe ni elela, you were willing to rejoice.

maadara $(\mathrm{gu}) \mathrm{n}$., forehead. S. dara.

maafu v. tr., to cover with wrappings; maafu maa, to blindfold.

maala an ulcer, a sore.

maaligwou v. i., to be thirsty. gwou 1 .

maalimaea enemy. mae.

maalitafa channel in reef. S. maalitawa.

maamana; ro maamana, father and son.

maasi v. tr., to await, expect.

maasia adj., while.

maauugala to mock at, used with poss.

mabe v. i., to be obedient, willing; manata mabe, patient. Cf. guvarimabe.

mabesi v. tr., to correct, rebuke.

madafi v. tr., to perceive, feel.

madalaba oven.

madiu adj., different, other, another, astray; too madiu gi, gentiles. madiua 1. exclam. well, I never! 2. adj. different. S. diu.

mae, mamae v. i., to die, to be ill, to be numb, to be eclipsed, of moon.

maeli v. tr., to die of; bae maeli, to condemn to death.

maea v. n., death, sickness.

maela (gu) v. n., death, danger.

maemaefa v. n., sickness. S. mae.

mafo v. i., to be healed. Mota mawo.

magu n. clothing; si magu.

mai 1. adv., here, hither, this way; ita ana mai, hither; ita mai logo, thence. S. mäi.

mai 2. transitive suffix to verb, ala, alamai; fatola, fatolamai. S. $m a^{\prime} i$. 
makalokalo adj., in the early morning, used with locative $i$. makeso adj., weak, feeble.

Mala 1. Malaita; Mala baita, Big Malaita; Mala Tou, Little Malaita.

mala 2. mala iteite v. tr., to wound. Cf. S. mala masi.

malefo shell money.

malengai coconut.

malimali adj., sweet. S. mälimeli.

malingi adj., split, overturned. S. malingi.

mamagu; v.i. bae mamagu, to revile.

mamagua n., weakness.

mamaloni adv., only, merely.

mamalu 1. (gu) n., a shadow; 2. v. i., to cast a shadow; sato e mamalu, it is towards evening. S. mamalu.

mamana v. i., to be true, real; doo mamana, truly; manata mamana, to believe.

mamanaa truly.

mamanaa n., power. S. nanama.

mana used of numerals over ten; aqala mana fai. U. mana.

manata 1. v. i., to think; manata suli to know; manata luga, to forgive; manata too (gu) to remember.

manatai v. tr. to pity.

manataila v. n., 1. pity, mercy; 2 . thought. S. manata. manata 2. v. i., to be quiet, tame. S. manata.

mani; qaimani, to help; qaimani fainau, help me; fatake qaimani, to be a peacemaker.

qaimania, v. n., a company. S. mäni.

manu bird. S. mänu.

manga time, occasion, place; $i$ kade manga, at the time; $i$ kade manga na, now; si manga uta, when?

mangata (na) n., midst, middle; used with loc. $i$. S. matanga.

mangisingisi adj., broken in pieces. ngi.

mango (gu) $\mathrm{n}$. life, breath; mango fu, to be sad; mango suu, to faint.

mangoli v. tr., to breathe upon. S. mango.

mao 1. v. i., to dance. 2. n., a dance.

maoli v. tr., to dance; maoli mao. S. mao.

mara- (gu) n. of own accord, alone. S. maraa. maraqai; alu maraqai, to become red and glowering, of sky.

marigo (gu) $\mathrm{n}$. flesh, body.

matafa- (na) n., too matafana, to know. S. mataqa.

matai, mamatai v. i., to have ague; matai afedali, fever.

mataia v. n., disease, a sick person; si mataia.

matala adj., lone, alone, merely; tefe mwela matala, only son.

matanga (na) n., midst, used with locative; $i$ mangata.

me for mai hither; lea fasi me, come here.

mea 1. (gu) n. tongue; 2 . v. i., mea too, to taste of.

meali v. tr., to lick.

meafa (na) v. n., tongue; meafana ere, tongues of fire. S. mea. 
meme in pieces; too meme to break in pieces.

mi 1. personal pron. pl. 1. excl. we; used by itself as subj. or follows gami.

mi 2. transitive suffix to verb; ano, anomi.

midi v. i., to taste; midi odonga ana, to taste of.

mode $\mathrm{v}$. tr. to mend, patch.

modela v. n., a patch.

moi adj., broken. S. 'o' $i$.

moko, momoko 1. v. i., to be corrupt, to smell; 2 . n., corruption.

mokola v. n., corruption;

mokofa- (na) v. n., the smell of.

molagali $\mathrm{n}$., all the islands; the world.

momoi v. tr. to buffet; afe e momoia na ola, the wind buffeted the ship.

momoko; momoko ia, breast, bosom.

mone adv., gives life to the narrative; tamone; otomone.

mori, momori, as mouri, to live. Cf. S. moli, walaimoli, mäuri.

morumoru v. i., to be broken in pieces. S. morumoru.

mou, momou, v. i., to fear.

mouni v. tr.

moumoula v. n., fear. S. mäu.

mouli to be left-handed, awkward. S. mäuli.

moumouli (gu) n., left hand.

mouri, momouri v. i., to live.

mourisi v. tr., to survive, escape from.

mouria v. n., life.

mourila- (gu) v. n., life. S. mäuri.

mousi v. tr., to cut off, sever. S. mousi.

mu. 1. pers. pron. pl. 2. used by itself as subj. or follows gamu; mu kafi lea mai $i$ angita, when will you come?

mu. 2. pronoun, suff. to nouns, sing. 2., thy.

mumudi crumb, chip, scrap; mumudi $i$ doo, scraps.

\section{MW}

mwaa snake. S. mwaa.

mwaela laughter. famwaela.

mwaemwae v. i., to be obedient. S. mwae.

mwai 1. a bag;

mwaila adj., rich. S. mwä'i.

mwai 2. prefix marking reciprocity of relationship; ro mwai telana, mother and child; ro mwai fungona geni, mother and daughterin-law; used as plural article, mwai asi nau, brethren. U. mwai.

mwaimwane, woman's brother, man's sister, a mwaimwane nau. mwaluda adj., soft, gentle, kind, possible, easy.

mwane, a male, man, boy, exclam. you! added to proper nouns and to certain other words to show sex distinction. S. mwane. mwaomwao v. i., to be weak, feeble. 
mwela, child, boy, person; used with article ni of women; ni mwela ne, this woman; mwela bibiu, little child. S. mwela.

mwemwedua honey.

\section{$\mathbf{N}$}

na 1. definite article, a, the; used with both sing. and pl.; gera na Grekia, the Greeks. Cf. Florida na. M. L.p. 524: na noni, the body; na sasigamu, your brethren; is in more frequent use than the corresponding nga in Sa'a; in many cases nouns are used without any article when the signification is general. S. nga.

na 2. pronoun suffixed to nouns, sing. 3 ; abana, his hand: added to the first of two nouns to express a genitive; $i$ tolona fera, on the tops of the hills; gwauna na ai gi, head of men: added to cardinals to form ordinals. S. $n \ddot{a}$, Mota na.

na, nana 3. demonstrative pron., there, that, follows noun; si doo $n a$, that thing.

na, nana 4 . adv. follows the verb and denotes a preterite, already, finished; e sui na, e sui nana, it is finished; sui na, thereafter.

naga $v$. tr., to waste, to spend.

namo, inner harbour, lake, pool; suu i namo; asi namo, a lake.

S. namo.

nana, na 3. 4.

nani, nanani, v. i., to seek for.

nanisi v. tr.

nao (gu) n. face; with locative $i$; in front of, before; naoe gula, first place; $i$ naogu, before my face; before my time, naonao tolia, chief portion at a feast.

nao v. i., to lead; nao tala, lead the way; eta inao, to lead. S. nao.

naofa (na) n. eldest, first, naofana mwela, eldest child, naofe mwela.

nare 1. v. tr., to roast on the embers.

nare 2 . v. tr., to prepare, make ready, serve, wait upon.

nau 1. pers. pron. sing. 1. I, used by itself as subj. or follows inau; nau gu ote nau ni lea, I do not want to go. V. nau.

nau 2. as nau 1. but suff. as obj. to verbs and prepositions.

nau 3. fanau educate. S. nanau.

ne 1. demonstrative, there, that; a mwela ne, that person, he.

ne 2. interrogative pron. follows the interrogative ati, who; ati ne? e uta ne, how is it?

ne 3. v. i., to speak, make a sound.

nee v. i., to be still, silent.

nena demonstrative pron., that, follows the noun; doo nena, that thing.

neneo charcoal. 
ni 1. genitive, of, belonging to; (a) used mainly in construction; fote ni fera, a native paddle; baea ni sugela, words of deceit, mwemwedua ni lalano, wild honey; (b) expressive of purpose, si gula ni lea inia, a place for him to go to; (c) expressive of condition, rosuli ni manatai gami, hear us in mercy, gera mou ni oli, they feared to return; fasia muka manata ni bae uri, think not to say thus; (d) added to verbal suffix giving transitive force; foaa, foaataini. S. ni. Cf. M. L. p. 532.

ni 2. personal article used with the names of females, both native and foreign; ni Alida, also used with certain nouns which denote women where in Sa'a nga or $a$ is used, ni te nau, my mother; ni mwaimwane, a man's sister or a woman's brother; ni aia, female relations; $n i$ doo the woman; ni mwela ne, that woman; is not used with afe wife, nor with geni female; is not used with plural. Duke of York ne, M. L. p. 566, Gilb. Is. nei, Efate lei, S. kei.

ni 3. interrogative used to (a) call attention; ni ai? I say, you! (b) in the sense of, is that so? S. ni.

ni 4. demonstrative attached to $t a$, one, a; tani aiai, some people; to oto; tani oto ni saiai. S. ni 3 .

ni 5. a detachable prefix; doo nifai, doo ifai, what thing? S. ni 4.

ni 6. transitive suffix to verbs; mou, mouni. S. ni.

ni 7. pers. pron. sing, 3 . it, used in explanation; na light fuana noni

ni maa, the light of the body is the eye; e uta ro si lio ni amu, why are you of two minds?

ni 8. suff. pron. pl. 3. neut; $i$ talani, in their place. S. $n i$.

nia personal pronoun sing. 3 . he, she, it; used by itself as subj. or

follows inia. S. nge'ie.

niania v. tr., to deny, repudiate.

nifai interrog. pron. what, follows noun; doo nifai, what thing?

nima, ninima 1. (gu) $\mathrm{n}$. hand, arm; ninimana tala, corner of the way, beside the way. S. nime.

nima 2. for lima five.

nina v. i. to be accustomed to, be able. S. nina.

noabu sparrow hawk.

noni (gu) n. body, shape, fashion; noni fii, to suffer; noni fila v. n., suffering; nonilau, to be safe and sound. Mao tino.

nono v. i., to place the face against, to sniff, to kiss; nono faini, to kiss.

nonoi v. tr. S. nono.

nue v. i., to be foolish, dumb.

nuela v. n., folly.

nui (na) n. a nest. S. niui.

nuku v. i., to be wrinkled. S. nuku.

nunulu v. i., to wither. S. nunulu. 
NG

ngado 1. v. i., to be firm; ngado fua, to trust, manata ngado ana, to rely on; too ngado, to remain firm.

ngado 2 . i aena ngado, at the very bottom. S. $i$ ngadona aena, at his feet.

ngae (na); adala i ngaena maa, envy. S. ngae.

ngaini transitive suffix to verb; sau, saungaini. S. nga'ini.

ngali 1 . v. tr., to take, to receive.

ngalila v. n., burden.

ngali 2. canarium nut. S. ngäli.

ngangarea adj., deep rooted.

ngasi v. i., to be firm, hard; bae ngasi, to speak sternly. Florida ngasi, hard.

ngi 1. v. tr., to divide; mangisingisi.

ngi 2. transitive suffix to verb; sau, saungi. S. ngi.

ngidu (gu) n., lip; ngidu auau fua, to hate. S. ngidu.

ngisi; fangisi, to acknowledge.

ngisu 1. v. i., to spit; 2 . n. fe ngisu, spittle.

ngisufi v. tr., to spit on. S. ngisu.

ngosa v. i., to bud; ngosa faolu, just come into bud.

ngongosa, a spike, a horn; ngongose doo.

ngu 1 . v. i., to sing; 2 . n. a song.

nguli v. tr., to sing; ngulia ngu, to sing a song.

o

o pers. pron. sing. 2. thou, used by itself as subj. or follows ioe. S. $o$. oa v. i. to share in.

oalangai v. tr., to distribute, to share in. S. 'oa.

oba v. tr., to take from, separate, divide. S. opa. Florida sopa.

obala v. n. separation.

odonga; midi odonga, to taste. S. ohonga.

odu v. tr., to command, order.

oe 1. an axe.

oe 2 . v. i. to commit adultery.

oela v. n., adultery.

ofosi v. tr., to take down. S. oohosi.

ofu 1. v. i., together; ofu bae, to witness; 2 . n. ofu si doo, a bundle.

ofu 3. v. i., to boil; ofu duqe, to burst. S. ohu.

oga (gu) n., stomach, belly. S. 'oqa.

ogi (gu) 1. n., bone.

ogi (gu) 2. n., back, outside.

ogila a bone needle.

ogo a band, a creeper used for binding. S. oko.

ogosi v. tr., to destroy, pull down, uproot. S. ooho'i.

ogu 1. v. i., to collect, gather together; ogu malefola, money collecting; 2 . adv., together, in company.

ogua v. n., company.

ogula v. n., ogule ai, a company of people. 
oi v. tr., to break off. S. 'o'i.

oimae exclam. alas!

okasa unripe; maea okasa, sudden death.

oku summer. S. oku.

ola canoe, ship. S. 'iola.

ole v. tr., to betray; ole ilalo deceit.

oli 1. v. tr., to hold in the arms.

oli 2 . v. tr., to return, go back; adv. back. S. 'oli.

olila v. n., return.

olisi v. tr., to answer; nia kafi olisida, then he answered them.

olitai partic. converted; olitai manata lau, repent.

olisusu v. i., to strive, quarrel, dispute, transgress; olisusu marana, to deny himself.

olo 1. v. i., to be deep.

olo 2 . v. i., to cry out.

olosi v. tr.; olosia riilana, cried out.

olu numeral, three, e olu.

oluna ordinal, third, for the third time. S. 'olu.

omae v. i., to weep.

omaea v. n., omaela v. n., wailing. Cf. oimae.

onionga, to mock, used with poss.; onionga ana, mocked him.

ono numeral, six; e ono.

onona ordinal, sixth, for the sixth time. S. ono.

ongataini v. tr., to vex, annoy.

ongiongi v. tr., to deceive.

00 a drum. S. 'o'o.

oobala a shed, hut.

oofa- (na) approaching to, with child.

ooga v. tr., to be tied together, to incur a debt.

ooganga v. n., debt.

oolo v. i., to be straight; adj. straight.

ooloa v. n., straightness.

ooni adv., temporary, empty, idle, naked; too ooni go, fleeting.

ore v. i., to fail, to fall short of, to lack; ore fanga, to abstain from eating, fast; ore fua to be lacking; ore ana, to be lacking; ani ore, to eat and leave some over. S. ore.

oro v. i., to be many; adj. many. faoroa.

oru 1. v. i., to blow; n. wind. S. ooru.

oru 2. widow; qe oru, a widow.

oso (gu) n. food for a journey. S. oto.

ote 1. plural article; ote ai gi, you women; ote ruana his fellows; ote geni women.

ote 2 . v. tr., to fash, cause ennui to; gera ote gera, it wearied them.

ote 3 . valley.

oto adv. perhaps; oto mone, is it so? denotes indefiniteness, used with $n i$ following, tani oto ni saiai, certain persons.

otofa- (na) because of, on account of. 


\section{Q}

The sound represented by $q$ is $k w$. In the words from Alite given by Dr. Codrington in M. L., p. p. $39 \mathrm{ff}$. the sound which appears in Lau as $q$ is there written as ku; e. g. kuai, Lau qai, Sa'a wai, water; $q$ in Lau may represent $w$ in Sa'a qato, waato; qalu, walu; Ulaqa, Ulawa.

qadangi v. tr., to open up.

qae 1. v. tr., to beat, strike; qae mousi, to strike and cut off; qae maeli to kill with blows.

qae; 2. qae tafusi, to strain.

qae; 3 . qae kudona, guiltless.

qai 1. prefixed to verbs, denotes reciprocity; sua, to encounter, qaisuasuafi, to meet; manata, to think, qaifamanatai to instruct; liu to move position, qailiu reciprocally; mani, (Sa'a mäni, altogether), qaimani, to stand together, be of help to. The action of the original verb is enlarged and the subject included.

qai 2. n., water; maana qai, mouth of the stream, a harbor on the northeast coast, south of Aio.

qai 3. v. tr., to load, to fill up.

qaiara n., a command.

qaiaraa n., reward.

qaidori v. tr., to desire.

qaidoria v. n., desire. dori.

qaiduu v. tr., to revenge.

qaiduula $v . n$., vengeance. $d u u$.

qaierisi v. tr., to command, importune.

qaierisia v. n., a command. erisi.

qaifamanatai v. tr., to instruct.

qaifamanataila v. n., instruction. manata.

qaife; qaife agalo to drive out evil spirits; mwane qaife agalo a witch doctor.

qailangaini v. tr., to wag, nod, waive. langa, up.

qailiu adv., reciprocally, used of mutual action; manata baita fuagamu qailiu, love one another; lea qailiu, to walk about. liu.

qailiua adj., humble, of low estate.

qaimaasi v. tr., to await, expect. maasi.

qaimanata v. tr., to have mercy upon, pity.

qaimanataia v. n., mercy. manata.

qaimani 1. v. tr., to help; qaimani fai, qaimani faini, to help; 2 . used as prep., together, in company with; 3 . v. i., to be reconciled with.

qaimania with one accord. S. mani.

qairaofai v. i., to agree with. rao to work.

qaisagali v. tr., to revolt, commit insurrection, take up arms, trouble, vex.

qaisagalia v. n., an insurrection.

qaisuasuafi v. tr., to meet, encounter. sua. 
qaisusu v. tr., to sacrifice.

qaisusia v. n., a sacrifice.

qaitaa v. i., to be a stranger; too ni qaitaa, to be a stranger. S. awataa.

qaitaga v. tr., to cause to scatter.

qaitali v. tr., to be disobedient to.

qala v. i., to lay an accusation; qala fafi, to accuse a person.

qalafi v. tr., to be delivered of a child.

qalu, 1. numeral, eight; e qalu.

qaluna, ordinal, eighth, for the eighth time.

qalu 2. v. i., to emerge; qalu tafa, to emerge from. S. wäru.

qanga $\mathrm{n}$., thunder, a gun.

qangafi of the lightning; sinamaaru ka qanagafia, the lightning 'thundered.'

qangareo v. i., to pass by.

qaqalifola v. i., to be pure, clean; fola qaqalifola, a great calm.

qaqalila adj., cold, of the weather.

qaqao adj., white, clean.

qarao a creeper used for tying; an iron nail. S. wa'arao.

qare v. tr., to castrate.

qarula adj., stony.

qate v. i., to make an oration, is preceded by lali; laliqate, to make

an oration; lali qatela v. n., an oration. S. wate.

qato a digging stick. S. waato.

qe 1. article; qe afe, a woman; qe oru, a widow; qe ia, a fish; na may

be prefixed; na qe ia gi, the fishes. Nengone, Gaua, wa, we,

M. L., p. 71 .

qe 2. a simpleton, fool; gera qe, fools.

qele, qeqele, v. i., used with poss., to wonder at, be surprised.

qelela v. n., wonderment, surprise.

qesu, qeqesu v. i., 1. to smoulder, burn; 2. to shine. S. 'eso.

qiqi n., a drop; qiqisi abu, drops of blood.

\section{$\mathbf{R}$}

raa v. i., to climb up.

raaraa $\mathrm{n}$., light, sunlight; na raaraa. S. raaraa.

rabu, rarabu, rabusi, v. tr., to hit, strike, beat. S. räpu.

rade $\mathrm{n}$., a reed; fe rade. S. rade.

rafai v. tr., to exalt, elevate.

rage (gu) n., mind, heart, womb; rage ruarua, v. i., to doubt; rage sasu, to be angry; rage sasua, rage sasula, anger.

rakaraka; abu rakaraka, a flow of blood.

ramo v. i., to be strong; ramo fua, to deliver.

ramola v. n., strength. S. ramo.

rao, rarao v. tr., to work; rao ana abana, his handiwork; rao uri, to do

like, to work at, to tend.

raoa v. n., raola v. n., work.

rara 1. v. i., to be withered, ripe.

rarasi v. i., to shrivel, dwindle. S. rara. 
rara 2. n., brightness, glory. S. rara.

rarafolo, stretched across, a crosspiece; ai rarafolo, a cross (late use).

S. lala'i.

rarangia adj., glorious.

raramaa v. i., to be excessive. S. raramaa.

rarao v. i., to stick, cling, cleave. S. rarao.

rarapu v. i., to reach, arrive at. S. arapu.

rarata a skull. S. rarata.

rarau v. tr., to kindle, light.

raunga weapons.

rauraua adj., soft, pliable.

rebo v. i., to be full grown, adult, old. S. repo.

reqeta $v$. tr., to open.

rereba v. i., to be broad, wide.

reresi; age reresi, a lily, Crinum asiaticum.

rigi v. tr., to see.

rigita $\mathrm{v}$. i., to be strong, firm. rigita fasi, to overcome.

rigitangaini v. tr., to do powerfully.

rii, riirii, to cry out; olosia riilana, cried out. S. rii, cicada.

ro 1 . v. tr., ro suli, to obey, listen to.

ro 2. numeral, two, used only in composition; forms part of pers. pronoun goro, etc.; ro si doo, two things; e ro mwane, two men. S. ro.

ro 3. numeral, two, used with nouns of relationship; ro mamana; ro mwai sasina.

ro 4. ending of pers. pronoun daro; gamoro. ro 2 .

rodo night; fe rodo, a night; rodo fi dao, till nightfall. S. rodo.

rogi yesterday; used with locative $i, i$ rogi.

rongo; fafurongo, v. i., to listen to, to be a disciple; n. a disciple. S. qaarongo.

rorodoa adj., dark, used also as $\mathbf{n}$., darkness. rodo.

roroi v. tr., to strengthen. S. roro'i.

rua numeral, two; e rua. S. rua.

ruana ordinal, second, second time; gera ruana gera, their fellows.

ruarua, tau ruarua, to be midway.

ruru (gu) 1. n. bosom, breast.

ruru; 2. ruru kore, an avalanche. S. ruru kore.

ruta $n$. dialect.

ruu v. i., to enter.

ruula v. n., entry.

\section{S}

sae 1. v. tr., to say, speak, tell, read; sae isingana, to finish speaking.

saetana, it is said. S. sae.

sae 2. adv. that, in reported speech.

saea adv. in order that, that so; saea o lea mai fuana, is it that you have come for this? denotes the subjunctive.

safali $\mathrm{v}$. tr., to be equipped with. 
saga v. i., to proceed; saga tafa to proceed out of.

sagali, sasagali, v. tr., to attack.

sai 1. n., place, duty, piece; sai i nonigu, my duty; sai oe, your duty; with ai 1. sai ai na, that one I mean; tani saiai, those which, in explanations.

sai; 2. sai gano, on the ground. S. hai. 2.

saitama (gu) v. tr., to know; gu langi si saitamana, I do not know; saitama dooa, knowledge.

sako v. tr., to catch. Mota sakau.

salo n. cloud, storm; salo uruuru, white fleecy cloud.

saloa adj., stormy. S. salo.

salofi v. tr., to prepare, clear a path, sweep.

samai v. tr., to fit on, to pair with. S. sama.

samola $\mathrm{n}$. pride, overbearing.

sangoni v. tr., to feed, nourish. S. sangoni.

sao sago palm, thatch. S. sa'o.

sara beach, shore.

sarii a maiden; geni sarii; too ni sarii, to be unmarried.

sarofaia adj., gentle; harmless, blameless; too sarofaia, quiet.

sarufi v. tr., to burn.

sasala adv., up, upwards; adj. light. S. sa'asala.

sasalu v. i., to start, arise.

sasalungaini v. tr., to collect, make ready.

sasara 1. (gu) n., limb, branch, member. S. sasara.

sasara 2. v. i., to warm oneself at a fire.

sasi 1. (gu) n., brother, sister; sasigu, my brother.

sasina n., of relationship; ro mwai sasina, two brothers. S. 'asi. sasi 2. to desire, used with fua; sasi fua, to desire; sasi diena fua, to love a person.

saso sun.

sasoai v. tr., to expose to the sun, dry. S. sato.

sasu 1. v. i., to smoke, of a fire. 2. n., smoke; rage sasu, to be angry; rage sasua, anger. S. sasu.

sata (gu) n., name; te satana, his name only; ati satamu, what is your name? with pers. pronoun, friend; sata nau, my friend.

sasata v. i., to be friendly with. S. sata.

sau 1. v. i., to kill; sau mwane, to commit murder; sau mwanea, murder.

saungi v. tr., to kill, to be ill of. S. säu.

sau 2. v. i., to become; sau ana mwane, to become man.

saufini 1 . v. tr., to turn away, to hide. 2. adv. secretly.

saulafi evening. S. säulehi.

saumala adv., granted that, even supposing.

saungaini v. tr., to make, construct.

se $n$., here: used with locative $i ; i$ se, at the place; $i$ sena, at that place, there.

seka, seseka, v. tr., to rend, tear.

sesele harlot. 
si 1. negative, not ; gu si saea, I do not know; langi may precede, gu langi si saea; e langi nau gu si lea, I am not going; follows the particles $k a, k o$.

si 2. article, a part, a piece, any; si fou, a stone; si manga uta, what time? na may be prefixed, na si baea taa ne, what words? si doo gu saea na, the thing (that which) I said; a si Eaea, the Word; is more definite and particular in meaning than na. U. mäsi.

si. 3. trans. suff. to verbs; ada, adasi.

si. 4. genitive; of $u$ si doo, bundles.

sie- (gu) n. used as preposition, to, towards, at, at the house of; lea go siena, go to him; siena ere, at the fire. S. sie.

sifo v. i., to go down; o sifo go; you go down. S. siho. sikeraini, v. tr., to free from, cast off. S. sikera'ini. siko locust.

sina, sinasina, v. i., to shine; fe bubulu sinasina, a bright star, n. light; sinasinana, its light. Mota singa.

sinali, moon, month.

sinalitaini, v. tr., to enlighten. S. sineli moonlight.

sinamaaru n., lightning; sinamaaru $k a$ qangafia, the lightning 'roared.'

sinatai v. tr., to keep from, beware of, guard.

siqa numeral, eight; e siqa.

siqana ordinal, eighth, the eighth time. S. siwe.

siramo used with prep. fua, fonosi, to resist, compel. S. ramo.

sisime a gnat. S. sime.

siu 1. v. i., to wash, bathe; siu abu, to baptize.

siufi v. tr.

siula v. n., washing, bathing.

siu, sisiu 2. v. i., to be conceived.

soe, sosoe, v. i., to call out, v. tr., to ask for, name; soea satana, ask his name.

soefataia, ecclesia, church (late use).

sofi v. tr., to find.

sofili v. tr., to collect, choose. S. so'ohi. sogoni v. tr., to gather, reap.

sogonila v. n., gathering. Mota. sogon. soi, sosoi, v. tr., to call; soi ledi, to question. S. soi. sua; 1 . qaisuasuafi, to meet. S. su'e. sua, suasua 2. n., dung; suasuae ano, dung. subi a club. S. supi. suda v. i., to root, of pigs. S. sude. sufi v. tr., to anoint, to rub, to shave with a razor. S. suhi. suge, susuge v. tr., to deceive; suge fafi, to accuse; qalaa susuge, to accuse falsely.

suli (nau) prep., after, according to, used of motion towards; the locative $i$ may precede. S. suli.

sulitalaa adj., safe, free. 
sulu n., oil, liquid. S. sulu.

sulufou 1. mound of rocks, stone wall; ui sulufou, to build a mound (for a tomb).

Sulufou 2. an artificial islet near Ataa Cove, North Malaita.

sunga, sungaini, sungataini v. tr., to affirm, maintain, persuade.

sungi v. i., to make a noise, be glad.

sungia v. n., a cry, a noise.

Suraina artificial islet South of Ataa Cove; original home of Lauspeaking people in Port Adam.

surakena; bae surakena, to prompt.

susu (gu) 1. n., breast, 2. v. i., to suck the breast, to have children at the breast. S. susu.

susu 3. v. i., to be firm; susu too, to be steadfast. S. susu.

susu 4. v. i., to stretch out; susu $a b a$, stretch out the arm. S. susu.

susui v. tr., to touch with the fingers, to set on a stick.

susubi n. a dry stick, a horn (late use).

susuli v. tr., to know, understand, be aware of; ati susulia, who knows? I can't say.

susia, adj. unfruitful, not bearing fruit.

suu 1. a harbour. S. su'u.

suu 2. used with prep. fafi; suu fafi, to clothe, cover.

suula v. n., clothing, cloak.

suu 3. v. i., to set, of heavenly bodies, to dive, go down, sink.

suula v. n., a setting. S. suu.

$\mathrm{T}$

ta 1. numeral; one, a certain one, at all; just, only. eta one; used as article, a, an, ta si fou, one rock; na tasi fou, one rock; ta sata nia, $a$ friend of his; $t a$ si doo, anything; ta ola lau, a different canoe; ta bali $a b a$, one hand, the other hand; e langi si suu ana ta toongi, not clothed in any clothing; ta sasina ta ai, a man's brother; ta ro ai, only two people; used with the numerals, ta ro si lio, two minds; ta ro tangale penny, two hundred pence; may precede fe, tefuana ta fe uo, every hill; ta ro fe lamua, just two doves; ni may be added, ta ni aiai, some other. S. ta'a; Rotuma ta; cf. Florida, sakai, M. L. p. 524. Wango $t a$ M. L. p. 511.

ta 2. adv. connects, resumes narrative, and, then.

ta 3. ending of verbal noun, seen in root afuta meaning ali, and used only with suff. pron.; afutagera, all of them. S. $t \ddot{a}$.

ta 4. adv. added to sui, sui ta, thereupon; follows negative langi, langi ta, or.

ta; 5 . ta mone, perhaps.

taa 1. interrog. pron. what? si taa na, what is it? S. taa.

taa 2 . v. i., to be bad, evil.

taala v. n., evil; ade taala, evil doing. S. ta'a.

taba with suff. ani, tabaani, v. tr., to destroy, remove. S. tapa.

tae v. tr., to lift up. S. $t a^{\prime} e$. 
tafa adv., out; bae tafa, to speak out.

tafangaini v. tr., sae tafangaini, to speak out. S. taha.

tafangi v. tr., to understand; liona e tafangia, he understood it.

tafe, a bed, bench, barn, bier. S. tahe.

tafi v. i., to flee.

tafila v. n., flight. S. tähi.

tafo 1. v. tr., to catch fish; tafo qe ia.

tafo 2. v. tr., to purchase;

tafoa v. n., a bought person, servant. S. taho.

tafua dung heap. S. älitehu.

tafusi v. tr., to strain; qae tafusi.

taga 1. v. i., to scatter, throw away.

tagaani v. tr.

taga 2. v. tr., to lay out, spread.

taga 3. v. i., to sprout, burst into leaf. S. taka.

tagala 1. v. i., to be lost.

tagalaini, tagalangaini v. tr., to drive away, cause to be lost.

tagalaa adj., promiscuously; ala tagalaa, feed here and there.

tagala 2. adj., irreverent; soe tagala, take one's name in vain. tataga. tagalo v. i., to be wandering.

tagalola adj., overgrown. S. takalo.

tagaloloa $n$., dust.

tagesi v. tr., to garnish, decorate, adorn.

tai 1. numeral, one; agala mana tai, eleven; taifili, alone. Wango. tai.

tai 2. v. tr., to mend.

taila v. n., a patch, seam.

tai 3. trans. suff. to verb; goni, gonitai; olitai participle.

taifili (a) alone; taifili gera, they alone. S. hili.

taini trans. suff. to verb; foaa, foaataini. S. ta'ini.

taingaini v. tr., to lay up, store up.

take, tatake, v. i., to stand; take fonosi, to guard. S. ta'e.

takedila v. tr., to cause to hit, knock.

takufi v. tr., to receive. S. täkuhi.

tala 1. way, path. S. tala.

tala 2. (gu) n., place, room; nao talagu, lead the way for me; rao talai fangala, work for food. S. tala.

tala 3. with prefix ma, matala, only, alone. S. tala 4.

talaa v. i., to shine, of sun.

talae v. i., to begin, to become; talae na ne, from this (that) time forth.

talaela, v. n., beginning. S. tala'ae.

talai, talani, partic., wantonly, for no reason. S. tale'i.

talatala v. i., to be diligent.

talo, with prefix aini; ainitalongaini, to proclaim. S. talo.

talu v. i., to sprinkle; talu fafi. S. danu.

tama- (gu), used with sae to know; nau gu sae tamana. I know (it).

tani some; tani oto ni saiai, some people. 
tangafulu, numeral, ten, used only in counting; e tangafulu.

tangafulu ana tenth, for the tenth time. S. tangahulu.

tangalau numeral, one hundred; e tangalau; tangale doo, one hundred things. S. tangalau.

taofai, tataofai v. i., to stumble.

taraina today, now, bye and bye.

tarakaukau a bramble. kakau.

tarau v. i., to be continuous, traditional.

taraungaini v. tr., to do continuously. S. tarau.

taru a chamber. S. duru.

tasa v. i., to be too much, used in comparison; nia baita tasaa ana, it is bigger than it.

tasala v. n., ro fe tasala, twice as much.

tasaa adj. excessive.

tasaliu v. i., to be in excess, exceedingly.

tata adjectival prefix; tatagwelu, headlong. S. tata.

tatabi; tatabi $i$ tala, a bifurcation of the path.

tatae v. i., to rise, arise; tatae oli, tatae olila, resurrection.

tataea v. n., a getting up, a steep place. S. $t a$ 'e.

tataga v. i., bae tataga, to speak blasphemously.

tatagala adj., bae tatagala, to speak blasphemously.

tatagwelu adj., headlong. S. tataqelu.

tatale v. tr., to uncover, reveal.

tatao v. i., to be flat, on one's back.

tau 1. v. i., to wash; tau $a b a$, to wash hands.

taufi v. tr.

tau 2. v. i., to be far off; be a long time; too ka tau, too ka tau, for ever and ever. S. ha'atau.

te 1. numeral, one, the same, a certain one; te ni ai, a certain person; da tefe bae ana te si baela, they all said the same thing; te si na doo, everything; te taifilia inia, he only; used of units (cf. Sa'a ata), te fiu fe doo, only seven things; te ai ma te ai, one by one; too te ai, singly; equivalent to and; te na Mwela, and the Son. Florida keha, one, Kingsmill te, M. L. p. 246.

te $2 . \mathrm{n}$., mother; ni te nau, my mother.

telana, n., of relationship, ro mwai telana, mother and child, wife. S. teitei.

tea v. tr., to utter, speak; e tea tesi baela nena, speaking the same words. S. tea.

tefe, te 1. fe 2.; da tefe bae ana tesi baela, they all (only) said the same thing; tefe mwela matala, an only son.

tefou with one accord, together, always.

tefua adj., irreverently, haphazard.

tefuana all, every, ta tefuana tani too, all peoples; te 1. fu.

tegelai partic., lost, dropped. S. tekela' $i$.

teo, teteo v. i., to lie down, sleep; teo bole, to dream; teo bolea, teo bolela, v. n., dream.

teteola adj., sleepy; maada e teteola, their eyes were sleepy. 
teqa v. i., to be tall, high.

teqala adj.; take teqala, to stand erect. S. tewa.

terefi v. tr., to move as a fan, to fan. S. tetere.

tero v. i., to be ulcerous, lame, halt, withered.

tete; 1 . manata tete, to be anxious.

tete; 2 . bubu tete, to look fixedly.

teu a wooden bowl, a measure.

ti interrogative pronoun, sing. who? pl. gerati; ti gera, one of them; with pers. article $a$, ati gera, who of them? ati satamu, what is your name? S. tei.

tobi v. tr., to gather, garner; n. a chamber.

toda v. i., to gain, get, collect; toda bata, a tax gatherer.

toe v. tr., to strike against, to desire; liona e toea, he desired it.

tofu, totofu v. tr., to chop.

tofuli v. tr., to build, to chop down. S. tohu.

tokekela (gu) n., judgment.

tolafa (gu) n., way, method, custom. S. tolaha.

toli down; ada toli, look down; dau tolingi, to cast down; toli fanga to fast, toli fangala, fasting.

tolingi v. tr., to apportion, give share to at a feast.

tolia v. n., a portion at a feast. S. toli.

tolo a hill, the hill country; toloe fera, a hill. S. tolo.

tona v. i.; liona e tona, he was pricked at the heart, afraid.

too 1. (gu) v. tr., to hit; sato toona, the sun struck it; too matafana, to know; manata toona, know it; too ani, understand; too meme, hit and break in pieces; 2 . to possess, have, too ai, to have relations.

tooa v. n., lio tooa, wisdom.

toonala v. n., manata toonala, thought.

too 3. v. i., to live, dwell, be; too laulau, to be whole; too salaa, to be a stranger, too ka tau, for ever. S. 'o'o.

toola (gu) v. n., way, fashion.

too 4. people, race; na too.

too 5. prefixed to numerals, at a time; too te ai, one at a time. S. too.

too 6. numeral, one thousand. S. to'o.

toongi 1. v. i., to clothe; n., clothes. S. tooni.

toongi 2. v. tr., to pack, load, place. S. tooni.

toromi v. tr., to pierce. S. toromi.

tosi v. tr., to throw away. S. 'asi.

tosiomelamwane a parable, proverb.

totolo v. tr., to raise the voice. S. totolo.

tou, totou, v. i., to be little; manata tou, to make little of; adj. little; ni ai tou, humbly.

toula v. n., manata toula, humility; toula (gu) in youth.

toula- (na), $i$ toulana asi, on the surface of the sea. 
U

ua adv., still, yet; ua mai inao, from of old; e mae ua na, already dead; ua mai ana lua, from the time of the flood, ua inao, old, aforetime; ua go $i$ uarodo, while still dark; e langi ua, not yet, still wanting. S. ue.

uarodo dawn, morning. rodo.

ubuubu v. i., to be thick, deep. S. 'upu.

uda v. i., to be new, fresh.

udu, uduudu, v. i., to drip, n., a drop. S. 'udu.

udufa v. n., a dropping, drops.

ueli v. tr., to happen adversely to.

ufi 1. v. tr., to blow; ufi bungu, to blow a conch shell.

ufiani v. tr., to breathe into, inspire. S. 'uhi.

ufi 2. a yam. S. uhi.

ufi 3. v. tr., to draw water.

uga v. i., to spill, to be wasted.

ugani v. tr., to grumble at. S. uqe.

ui, uiani v. tr., to throw, cast. S. ' $u$ ' $i$.

ulu v. i., to wade.

ulufaini v. tr., to carry a person over water. S. ulu.

ulufi v. tr., to vex, grieve. S. unuhi.

ulunga, urunga, to serve as a pillow; n., a pillow.

urungai v. tr., to recline the head. S. ulunge.

umu oven. S. umu.

unua n., folk lore, a yarn. S. unu.

unga (gu) $\mathrm{n}$., skin.

uo hill; fe uo. S. uo.

uri 1. v. tr., to tread, tread on; uri sufu, to tread through.

urila v. n., tread, step. S. uri.

uri, urina, 2. adv., like, thus; nia kafi uri, he spake thus, rao uri, to do like, to tend, ele uri, to desire. S. uri.

uria adj., like, used as adv., toolada ka uria alafana, their way shall be like as if.

urii adv., just now.

uruuru; si salo uruuru, fleecy cloud.

usi (nau) prep., over, for, on behalf of.

usia n., a market; $i$ fuli usia, in the market place. S. usie.

usu v. tr., to wipe, anoint. S. usu.

usungaia n., commandment. S. usunge'i.

uta 1. n., rain; v. i., to rain; na uta ka uta, the rain rains. Florida wha.

uta 2. adv., interrog. how? si manga uta, what time? nia kafi uta, what will he do? S. u'e.

uwa v. tr., to lift; uwa maa, to lift the eye. S. uwe. 



